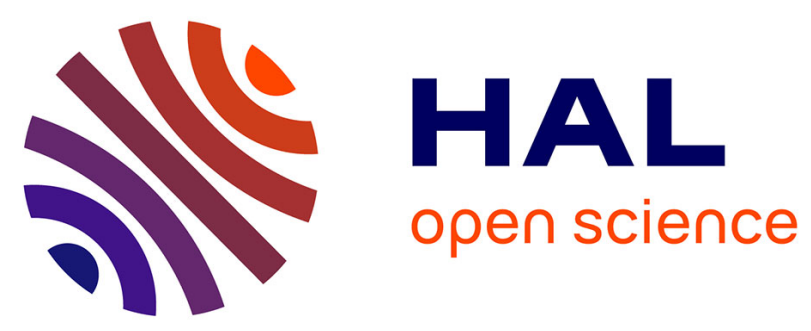

\title{
Nighttime ozone profiles in the stratosphere and mesosphere by the Global Ozone Monitoring by Occultation of Stars on Envisat
}

Erkki Kyrölä, J. Tamminen, G.-W. Leppelmeier, Viktoria Sofieva, S. Hassinen, A. Seppälä, P.-T. Verronen, Jean-Loup Bertaux, Alain Hauchecorne, Francis Dalaudier, et al.

\section{To cite this version:}

Erkki Kyrölä, J. Tamminen, G.-W. Leppelmeier, Viktoria Sofieva, S. Hassinen, et al.. Nighttime ozone profiles in the stratosphere and mesosphere by the Global Ozone Monitoring by Occultation of Stars on Envisat. Journal of Geophysical Research: Atmospheres, 2006, 111 (D24), pp.D24306. 10.1029/2006JD007193 . hal-00133425

\section{HAL Id: hal-00133425 \\ https://hal.science/hal-00133425}

Submitted on 4 Feb 2016

HAL is a multi-disciplinary open access archive for the deposit and dissemination of scientific research documents, whether they are published or not. The documents may come from teaching and research institutions in France or abroad, or from public or private research centers.
L'archive ouverte pluridisciplinaire $\mathbf{H A L}$, est destinée au dépôt et à la diffusion de documents scientifiques de niveau recherche, publiés ou non, émanant des établissements d'enseignement et de recherche français ou étrangers, des laboratoires publics ou privés. 


\title{
Nighttime ozone profiles in the stratosphere and mesosphere by the Global Ozone Monitoring by Occultation of Stars on Envisat
}

\author{
E. Kyrölä, ${ }^{1}$ J. Tamminen, ${ }^{1}$ G. W. Leppelmeier, ${ }^{1}$ V. Sofieva, ${ }^{1}$ S. Hassinen, ${ }^{1}$ A. Seppälä, ${ }^{1}$ \\ P. T. Verronen, ${ }^{1}$ J. L. Bertaux, ${ }^{2}$ A. Hauchecorne, ${ }^{2}$ F. Dalaudier, ${ }^{2}$ D. Fussen, ${ }^{3}$ \\ F. Vanhellemont, ${ }^{3}$ O. Fanton d'Andon, ${ }^{4}$ G. Barrot,${ }^{4}$ A. Mangin, ${ }^{4}$ B. Theodore, ${ }^{4}$ \\ M. Guirlet, ${ }^{4}$ R. Koopman, ${ }^{5}$ L. Saavedra de Miguel, ${ }^{5}$ P. Snoeij, ${ }^{6}$ T. Fehr, ${ }^{5}$ Y. Meijer, ${ }^{7}$ \\ and R. Fraisse ${ }^{8}$
}

Received 13 February 2006; revised 9 June 2006; accepted 15 August 2006; published 27 December 2006.

[1] The Global Ozone Monitoring by Occultation of Stars (GOMOS) instrument on board the European Space Agency's Envisat satellite measures ozone and a few other trace gases using the stellar occultation method. Global coverage, good vertical resolution and the self-calibrating measurement method make GOMOS observations a promising data set for building various climatologies. In this paper we present the nighttime stratospheric ozone distribution measured by GOMOS in 2003 . We show monthly latitudinal distributions of the ozone number density and mixing ratio profiles, as well as the seasonal variations of profiles at several latitudes. The stratospheric profiles are compared with the Fortuin-Kelder daytime ozone climatology. Large differences are found in polar areas and they can be shown to be correlated with large increases of $\mathrm{NO}_{2}$. In the upper stratosphere, ozone values from GOMOS are systematically larger than in the Fortuin-Kelder climatology, which can be explained by the diurnal variation. In the middle and lower stratosphere, GOMOS finds a few percent less ozone than Fortuin-Kelder. In the equatorial area, at heights of around 15-22 km, GOMOS finds much less ozone than Fortuin-Kelder. For the mesosphere and lower thermosphere, there has previously been no comprehensive nighttime ozone climatology. GOMOS is one of the first new instruments able to contribute to such a climatology. We concentrate on the characterization of the ozone distribution in this region. The monthly latitudinal and seasonal distributions of ozone profiles in this altitude region are shown. The altitude of the mesospheric ozone peak and the semiannual oscillation of the number density are determined. GOMOS is also able to determine the magnitude of the ozone minimum around $80 \mathrm{~km}$. The lowest seasonal mean mixing ratio values are around $0.13 \mathrm{ppm}$. The faint tertiary ozone peak at $72 \mathrm{~km}$ in polar regions during wintertime is observed.

Citation: Kyrölä, E., et al. (2006), Nighttime ozone profiles in the stratosphere and mesosphere by the Global Ozone Monitoring by Occultation of Stars on Envisat, J. Geophys. Res., 111, D24306, doi:10.1029/2006JD007193.

\footnotetext{
${ }^{1}$ Earth Observation, Finnish Meteorological Institute, Helsinki, Finland ${ }^{2}$ Service d'Aeronomie du Centre National de la Recherche Scientifique, Verrieres-le-Buisson, France.

${ }^{3}$ Institut d'Aeronomie Spatiale de Belgique, Brussels, Belgium.

${ }^{4}$ ACRI-ST, Sophia-Antipolis, France. Italy.

${ }^{5}$ European Space Research Institute, European Space Agency, Frascati,

${ }^{6}$ European Space Research and Technology Centre, European Space Agency, Noordwijk, Netherlands.

${ }^{7}$ Laboratory for Environmental Measurements, Environmental Risks and Safety Division, National Institute of Public Health and the Environment, Bilthoven, Netherlands.

${ }^{8}$ EADS-Astrium, Toulouse, France.

Copyright 2006 by the American Geophysical Union. 0148-0227/06/2006JD007193
}

\section{Introduction}

[2] The dramatic loss of ozone in the Antarctic (the socalled ozone hole), the similar but weaker loss of ozone in the Arctic, and the general slow decline of ozone in the stratosphere have been the object of intensive experimental and modeling studies since 1985, when the ozone hole was first discovered (for reviews, see, e.g., Solomon [1999] and Staehelin et al. [2001]). It was soon recognized that we need to study not only the total ozone content in the atmosphere but also changes in the vertical profile of ozone and other trace gases which provide important insights to the mechanisms of the decline of ozone [Harris et al., 1999]. It is natural to expect that the predicted recovery of ozone will also be an altitude-dependent process.

[3] The vertical profile of ozone can be measured in various ways from the ground, balloons, and satellites (for 
reviews, see Grant [1989] and Harris et al. [1999]). In situ measurements are possible by balloon-borne sondes [Logan, 1994] up to about altitudes of $30 \mathrm{~km}$. Higher altitudes can be reached from ground by lidars and microwave sounders. The Dobson and Brewer spectrometers that are used to measure total ozone can also provide ozone vertical profiles (using the so-called Umkehr technique) but the vertical resolution is poor. The global coverage cannot be reached by any of these measurements. On the contrary, satellite measurements, especially from polar orbiting satellites, can provide measurements from all over the world. Satellite instruments can be divided into nadir- and limbviewing types. The nadir-viewing instruments (like TOMS, SBUV, SBUV2, GOME, OMI) excel in total ozone measurements but rough ozone profiles can also be derived from these measurements. The limb-viewing instruments are by the nature of the viewing geometry best suited for ozone profile measurements. Limb-viewing instruments utilize direct attenuation of solar or stellar light or measure scattered solar light. Thermal emissions from the atmosphere can also be used to retrieve ozone and other constituent profiles during day and night (for example, MLS on UARS [Barath et al., 1993]). The most important limb instruments have so far been solar occultation instruments. The longest measurement series comes from the SAGE family [see, e.g., Chu et al., 1989]. Other important solar occultation instruments are POAM II [Glaccum et al., 1996] and POAM III [Lucke et al., 1999] on SPOT satellites, and HALOE on UARS [Russell et al., 1993]. An important benefit of the occultation technique is the selfcalibration principle. This makes it possible to create longtime measurement series, free of degrading effects due to instrument aging or data discontinuities when a new instrument replaces an old one.

[4] Recently five new satellites have been launched carrying an impressive collection of instruments capable of ozone profiling. The Swedish small satellite Odin was launched into a polar orbit in 2001. It carries two instruments and both are able to measure atmospheric profiles [Murtagh et al., 2002]. The optical spectrograph OSIRIS scans scattered solar light from the limb in order to retrieve ozone and $\mathrm{NO}_{2}$ profiles. Odin's submillimeter radiometer SMR exploits limb emissions in the sub-mm region to retrieve several trace gases including ozone. The Meteor$3 \mathrm{M}$ satellite was launched in 2001 and it has on board a new member of the SAGE-family, the SAGE III instrument. The TIMED satellite was launched in 2001 and carries on board the SABER instrument [Russell et al., 1999]. SABER measures limb emissions in the midinfrared and retrieves several trace gases, including ozone. The Envisat satellite was launched in 2002 into a polar orbit carrying three atmospheric instruments, SCIAMACHY, MIPAS and GOMOS. All three instruments use limb viewing to probe the stratosphere and partly also the troposphere and the mesosphere. SCIAMACHY uses a limb-scattering technique in the ultraviolet, visible and near IR wavelengths and it is also able to perform solar occultation and nadirviewing measurements [Bovensmann et al., 2004]. Several trace gases, including ozone, are measured. MIPAS measures thermal emissions from the limb [Fischer and Oelhaf, 1996] and produces vertical profiles of numerous trace gases. GOMOS exploits the stellar occultation method in the ultraviolet-visible region and its main focus is to perform ozone profile measurements. (For references, see below.) EOS-Aura was launched in 2004. It carries the total ozone instrument OMI, the microwave limb sounder MLS (earlier on UARS), the infrared radiometer HIRDLS, and the tropospheric emission sounder TES. (See the special EOS-Aura issue in IEEE Transactions on Geoscience and Remote Sensing, 2006.)

[5] The new instruments provide continuation of some earlier measurements (MLS, OMI, SAGE) but also extend the species coverage, the global coverage and temporal sampling. The large number of constituents retrieved from measurements allows an increasing understanding of atmospheric processes especially when used in conjunction with atmospheric models. In this paper we concentrate on presenting the contribution that the GOMOS instrument provides for the understanding of the global ozone profile distribution. In section 2 we present the GOMOS instrument and mission, the retrieval approach and characteristics of the data. In section 3 we present data selection for the present study. The results for the stratosphere and comparisons of results with the Fortuin-Kelder climatology are shown in sections 4 and 5, respectively. In section 6 we show GOMOS results for the mesosphere and the lower thermosphere.

\section{GOMOS}

\subsection{GOMOS Instrument}

[6] GOMOS (Global Ozone Monitoring by Occultation of Stars) is a stellar occultation instrument on board the European Space Agency's Envisat satellite [see Bertaux et al., 1991, 2000, 2004; Kyrölä et al., 2004; European Space Agency, 2001; http://envisat.esa.int/dataproducts/gomos]. GOMOS first acquires a star when the star is seen well above the atmosphere. This starting altitude is presently $150 \mathrm{~km}$. Measurements at $150-130 \mathrm{~km}$ are used to determine the star's undisturbed spectrum (the reference spectrum). As the satellite moves along its orbit the observed star appears to descend through the Earth's atmosphere and the star's spectrum is recorded with 0.5 or $0.25 \mathrm{~s}$ integration time. Horizontal transmission spectra can be constructed from these occulted spectra and the reference spectrum. The spectral and intensity distribution of the transmission carries imprints from the interactions of light with various molecules and aerosols along the path joining the instrument and the star. Knowing the absorption and scattering cross sections of the atmospheric constituents, their altitude profiles can be retrieved. GOMOS makes several hundred occultations per day and it can measure in both day and night conditions.

[7] The GOMOS instrument has a large scanning mirror controlled by a star tracker. Light is forwarded through a slit to the two holographic gratings and to the two fast photometers. During nighttime measurements the slit is not needed but during daytime measurements the slit restricts the intrusion of scattered solar light into the instrument. For daytime measurements the scattered solar light increases the measurement noise in occultation retrievals but it also provides an additional data source for retrievals (similar to OSIRIS and SCIAMACHY).

[8] The spectrally resolved light is recorded by CCD detectors. Three spatial bands are read from the CCDs: 

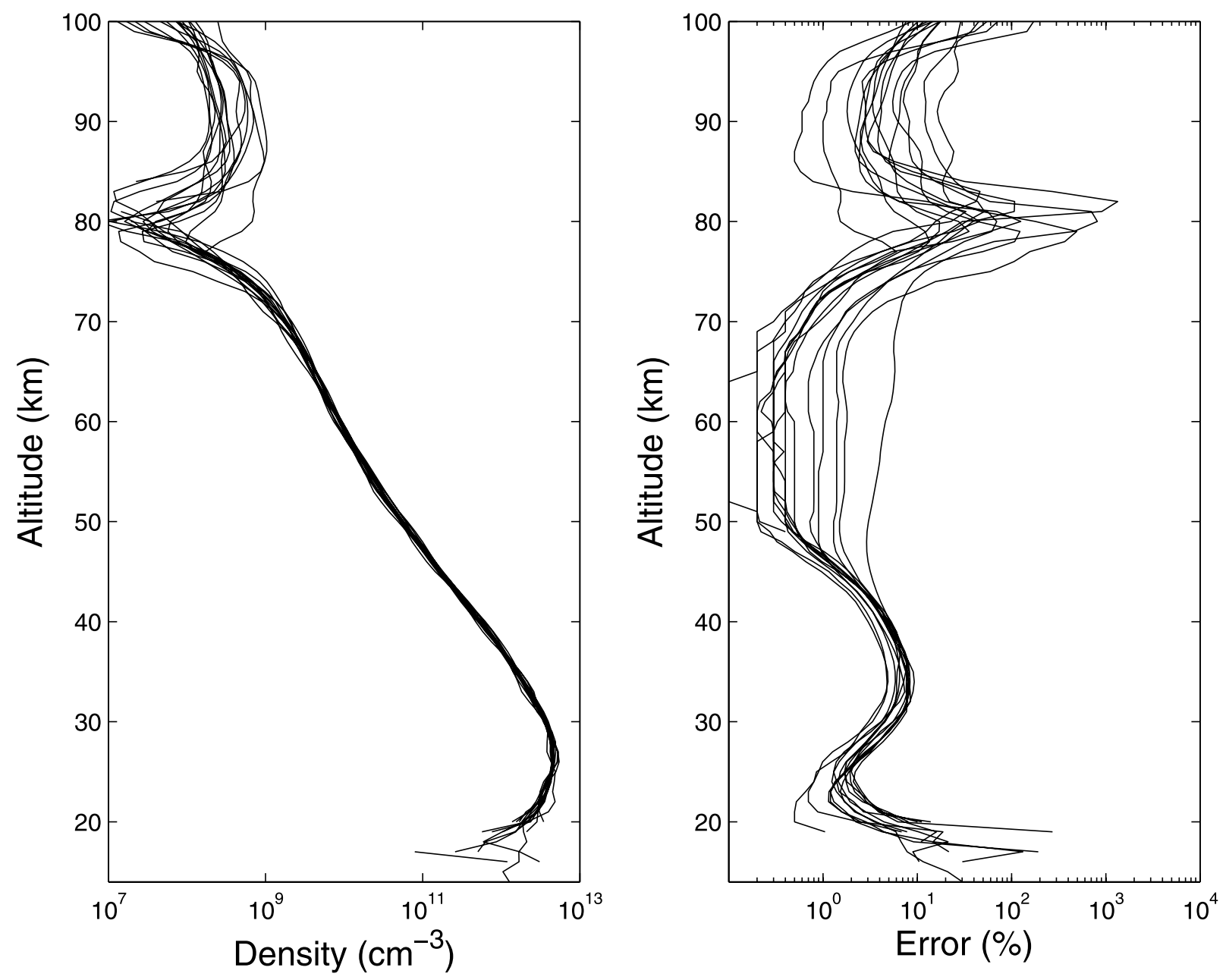

Figure 1. Ozone profiles and estimated errors from GOMOS measurements in the equatorial belt $10^{\circ} \mathrm{S}-$ $10^{\circ} \mathrm{N}$ in 2003 . All stars shown are hotter than $7000 \mathrm{~K}$ and brighter than the visual magnitude 1.9. Only one measurement from each star included has been drawn.

the stellar band and the upper and lower limb bands. In dark limb occultations only the stellar band is used to calculate the transmission function. In bright limb occultations the upper and lower bands are used to estimate the magnitude of the scattered solar light in the stellar band. The spectral ranges are $250-690 \mathrm{~nm}, 750-776 \mathrm{~nm}$, and 916-956 nm which enable retrieval of vertical profiles of $\mathrm{O}_{3}, \mathrm{NO}_{2}, \mathrm{NO}_{3}$, $\mathrm{H}_{2} \mathrm{O}, \mathrm{O}_{2}$, neutral density, and aerosols. The altitude sampling resolution is better than $1.7 \mathrm{~km}$. The two photometers work at blue and red wavelengths at a frequency of $1 \mathrm{kHz}$. Data are used to make the scintillation correction for the spectrometer data. From the photometer data it is also possible to retrieve high-resolution (resolution of $200 \mathrm{~m}$ ) temperature profiles in the range of $15-40 \mathrm{~km}$ using the spatial separation of rays by chromatic refraction. Moreover, photometer data can be used for middle atmosphere turbulence studies [Gurvich et al., 2005].

[9] GOMOS is the first operational stellar occultation instrument but the first such measurements were made already 30 years ago [Hays and Roble, 1968; Roble and Hays, 1972]. Recently the UVISI instrument on board the MSX satellite has carried out stellar occultations successfully during 1996-2001, providing samples of ozone profiles in the stratosphere [Yee et al., 2002].

\subsection{GOMOS Retrieval}

[10] The GOMOS constituent profile retrieval is based on the transmission spectra [see Kyrölä et al., 1993; Sihvola, 1994; http://envisat.esa.int/dataproducts/gomos]. Occultations are processed one at a time. The data processing is split into level $1 \mathrm{~b}$ and level 2 stages. In level $1 \mathrm{~b}$ dark charge removal and a few other instrumental corrections are performed on the CCD counts and transmission spectra are constructed. In bright limb occultations the estimate of the scattered solar light (using upper and lower bands) is removed from the stellar band counts. Geolocation is determined starting from the satellite location and from the known direction to the star, and performing the ray tracing calculation through the neutral atmosphere given by the ECMWF and MSISE-90. Besides transmissions, other level $1 \mathrm{~b}$ products are limb radiances from the upper and lower CCD bands and photometer time series.

[11] In level 2 processing the transmission spectra are corrected first for the attenuation (or dilution) caused by refraction and modulations by scintillations. The fast photometer data are used in the scintillation correction. The correction procedure [Dalaudier et al., 2001] is based on the hypothesis of strong anisotropy of air density irregularities; 

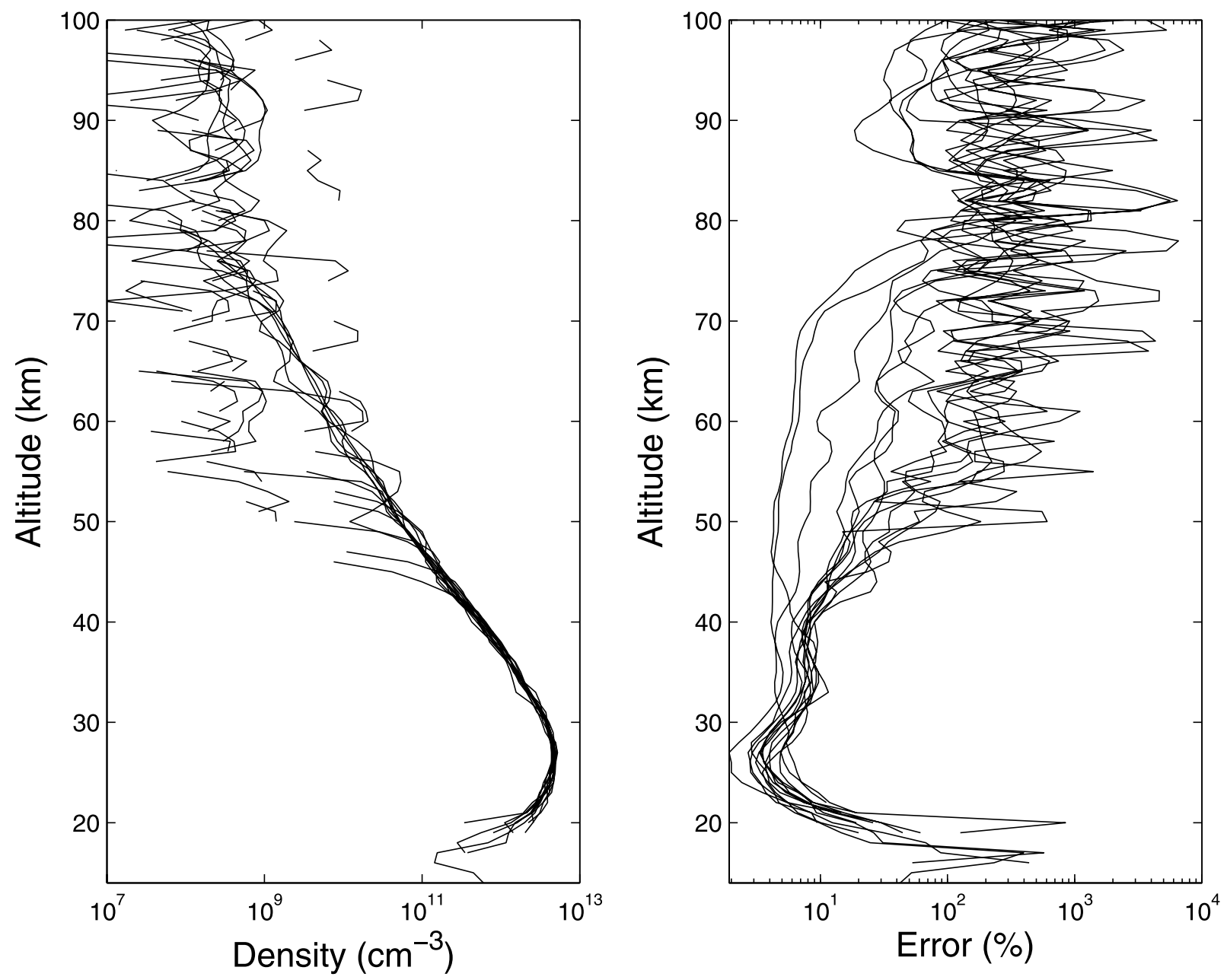

Figure 2. Same as in Figure 1 but all stars shown are cooler than $7000 \mathrm{~K}$ and dimmer than the visual magnitude 1.9 .

that is, the density is assumed to be a function of the vertical coordinate only. The correction does not remove the scintillation modulation completely in case of off-orbital occultations through a turbulent atmosphere. However, the ozone retrieval is only weakly sensitive to modulations by scintillations. Simulations show that even completely skipping scintillation correction leads to less than $2 \%$ error in the ozone retrieval. The current scintillation correction enhanced by a GDI (Global DOAS iterative) method [Hauchecorne et al., 2005] makes the influence of scintillations on the ozone retrieval quality negligible.

[12] After refractive corrections the processing is divided into three lines according to wavelength region. Ozone as well as $\mathrm{NO}_{2}, \mathrm{NO}_{3}$, aerosols and neutral density retrievals are performed with the ultraviolet-visible range $250-687 \mathrm{~nm}$. The retrieval of $\mathrm{H}_{2} \mathrm{O}$ and $\mathrm{O}_{2}$ is performed with the two infrared channels. This retrieval does not interfere with the object of this work (ozone is retrieved only from UV-VIS) and it will not be elaborated further. The UV-VIS retrieval is divided to two consecutive stages. In the first stage, called the spectral inversion, the model transmission function is fitted to the refraction-corrected transmissions simultaneously at all wavelengths by a nonlinear Levenberg-
Marquardt method [Kyrölä et al., 1993; Sihvola, 1994]). This absolute cross section method had to be modified after it was realized (after launch) that in real measurements (as opposed to prelaunch simulations) isotropic scintillations modify transmissions in such a way that the scintillation correction method was not able to remove these modifications. Therefore $\mathrm{NO}_{2}, \mathrm{NO}_{3}$ retrieval had to be based on subiteration using differential cross sections [Hauchecorne et al., 2005].

[13] After spectral inversion a vertical inversion is performed using the onion-peeling method. A smoothness constraint is applied to the inversion using the target resolution Tikhonov method [Sofieva et al., 2004]. For ozone the target vertical resolution is $2 \mathrm{~km}$ below $30 \mathrm{~km}$, increases linearly to $3 \mathrm{~km}$ at $40 \mathrm{~km}$, and remains the same above that. An iteration loop over spectral and vertical inversion is performed in order to take into account the temperature dependence of the cross sections. This loop is necessary because temperature-dependent cross sections in the extinction line-of-sight integrals (Beer-Lambert formula) couple the spectral and vertical inversion problems (for more details, see Kyrölä et al. [2004]). 


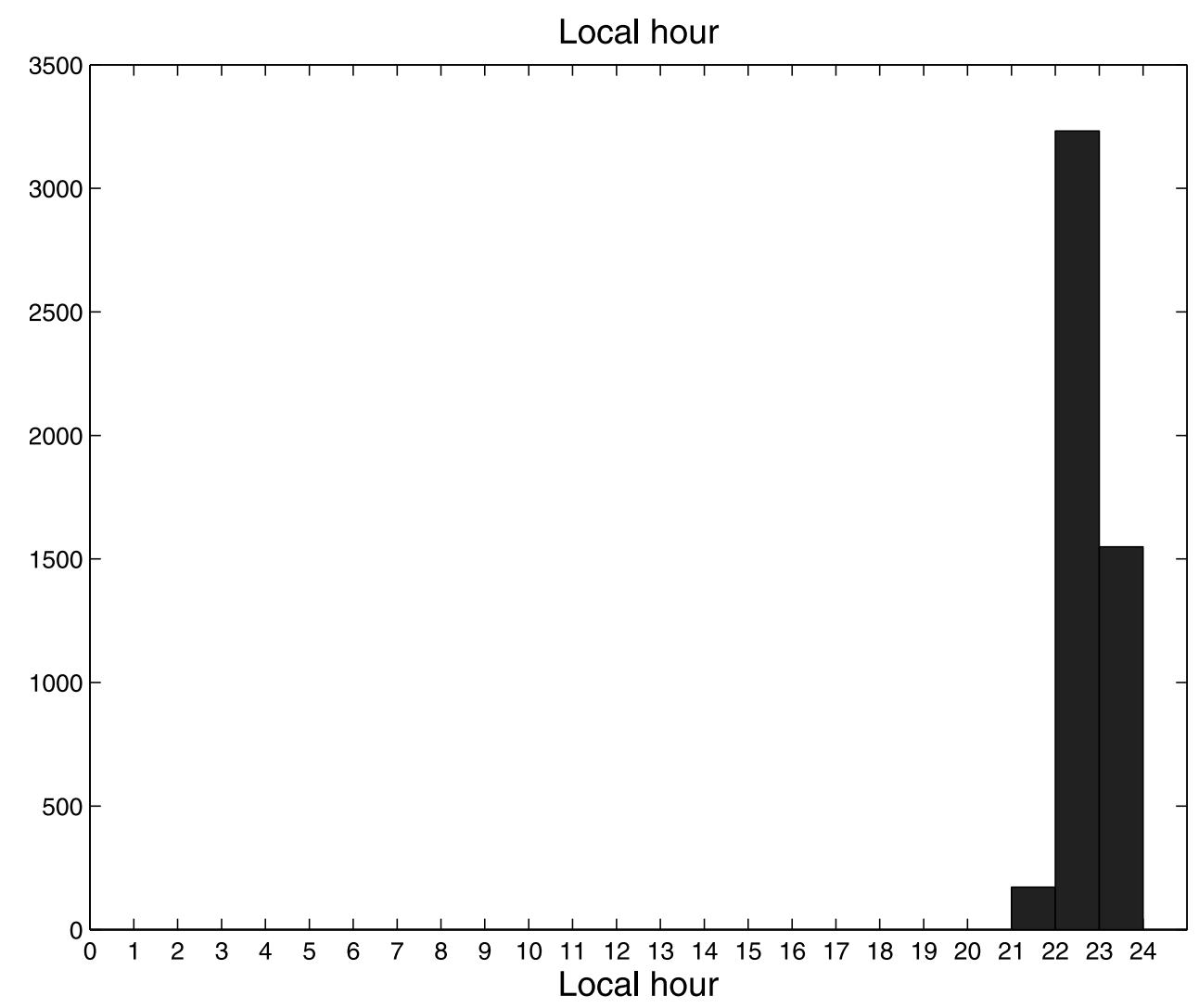

Figure 3. Local hour distribution for dark limb (solar zenith $>108^{\circ}$ ) measurements in the equatorial belt $10^{\circ} \mathrm{S}-10^{\circ} \mathrm{N}$.

[14] The error estimation is based on the propagation of all level $1 \mathrm{~b}$ errors, the largest contributors of which are dark current and photon noise, through the spectral and vertical inversions. An additional error source in level 2 is the step where intensity fluctuations from scintillations are removed using photometer data. This additional error is estimated from large numbers of equatorial measurements with varying azimuth angle. The underlying assumption is that the ozone distribution around the equator is relatively constant and the variability of ozone profiles comes from the scintillations. The degree of scintillation error depends on the azimuth angle.

[15] The validity regions of retrieved constituents vary, depending on the type of the occulted star and the state of the atmosphere. The valid altitude range of ozone retrievals is generally $15-100 \mathrm{~km}$. Other constituents have more limited validity ranges between 20 and $50 \mathrm{~km}$. Examples of retrieved ozone profiles and their error estimates are shown in Figures 1 and 2.

\subsection{Properties of GOMOS Data}

[16] During 2003, the first full operational year of GOMOS, 177 different stars were used for occultations. In addition, a few planetary occultations were performed. A typical orbit included 30-50 occultations each lasting from 40 to $255 \mathrm{~s}$. About 102,000 stellar occultations were executed altogether. The number was lower than expected because GOMOS suffered a temporary electronic malfunction of the mirror steering mechanism in May-June 2003.
By using the redundancy in GOMOS electronics measurements were able to continue in July 2003 without loss of performance. A similar but more serious problem was encountered in January 2005. After a tedious testing phase measurements were resumed in the end of August 2005 but with a restricted pointing range. The number of available targets per orbit decreased to $65 \%$ of the original number.

[17] The multitude of available and suitable stars provides a much better global coverage than by solar occultation measurements but the signal-to-noise ratio is much lower and it varies from one occultation to another according to the visual magnitudes of stars. Less obvious is the influence of the spectral type of a star, which is approximated by the effective temperature of the star. Cool stars emit mainly in the visible region but very little at ultraviolet wavelengths where the spectra of hot stars peak. At high altitudes, above $45 \mathrm{~km}$, the atmosphere is almost transparent at visible wavelengths but the Hartley and Huggins absorption bands of ozone at $250-350 \mathrm{~nm}$ absorb very strongly. Consequently, only occultations of hot stars are able to provide information about ozone at high altitudes. At lower altitudes the Chapman absorption band of ozone around $600 \mathrm{~nm}$ interacts strongly with the visible radiation from cool stars and provides the basis for the ozone retrieval.

[18] In addition to the star type, the overall retrieval accuracy of GOMOS depends on the solar zenith angle at the tangent point and on the angle of the viewing direction with respect to the orbital plane of the satellite. As already stated, GOMOS retrievals during the daytime and also near 


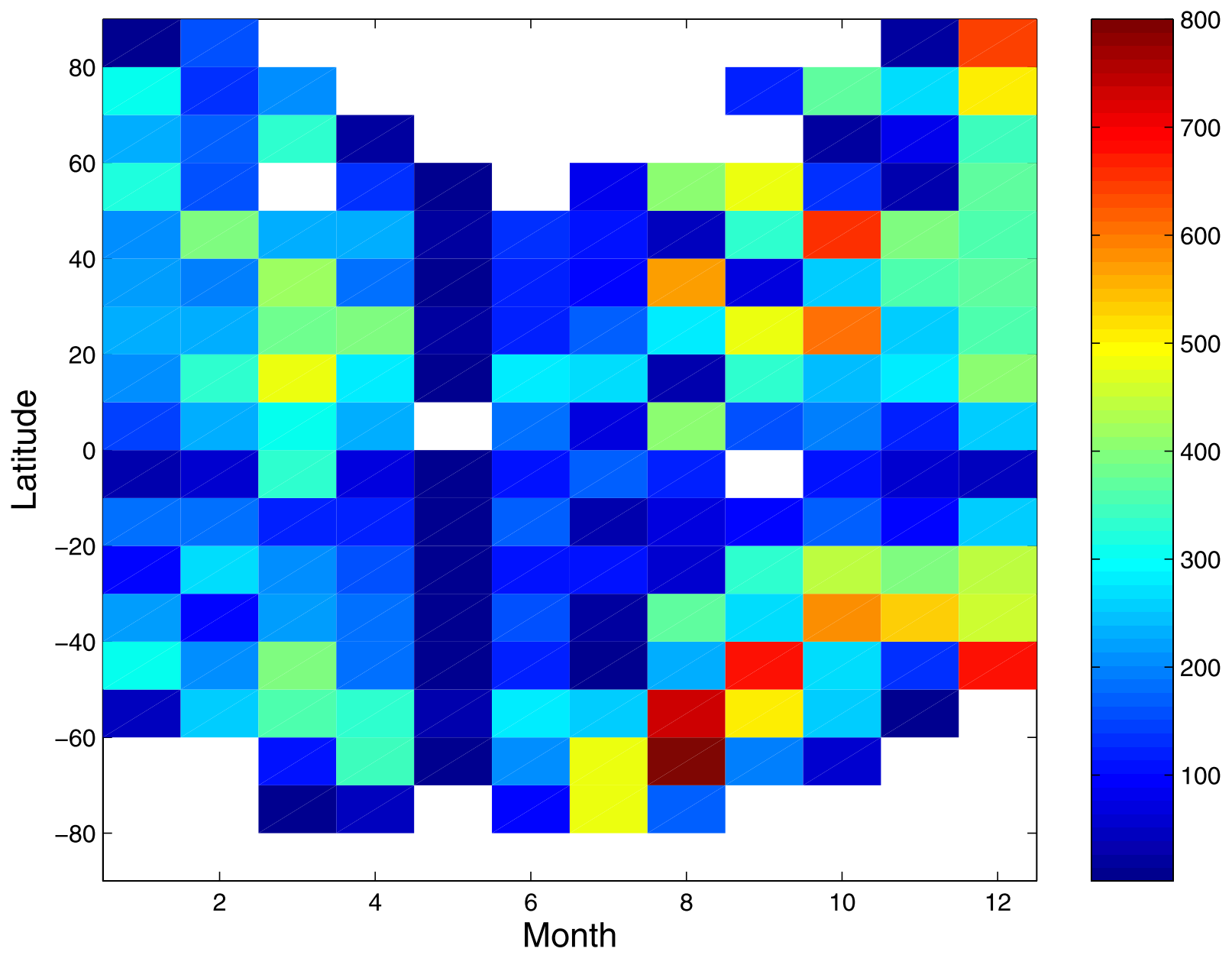

Figure 4. Number of dark limb GOMOS profiles in 2003 on a latitude-time grid. The stopping altitude of occultations in this figure has been required to be $20 \mathrm{~km}$ or lower. The white color means none or only one measurement in the grid cell. The white areas in polar regions are due to the dark limb restriction.

sunset or sunrise suffer from additional noise caused by the scattered solar light. The dependency on the viewing angle is related to scintillations that are not completely removed from the data.

[19] The GOMOS data validation activity has been carried out since the summer of 2002. The comprehensive validation of ozone against ground-based and balloon-borne instruments has been presented in [Meijer et al., 2004]. The results show that in dark limb the GOMOS data agree very well with the correlative data: between 14 and $64 \mathrm{~km}$ altitude their differences show only a small (2.5-7.5\%) insignificant negative bias with a standard deviation of $11-$ $16 \%(19-63 \mathrm{~km})$. This conclusion was demonstrated to be independent of the star temperature and magnitude and the latitudinal region of the GOMOS observation, with the exception of a slightly larger bias in the polar regions at altitudes between 35 and $45 \mathrm{~km}$. GOMOS, MIPAS and SCIAMACHY measurements have been compared by Bracher et al. [2005]. In the mesosphere and lower thermosphere (MLT hereinafter) only satellite data are available for validation purposes. GOMOS results have been compared with MIPAS [Verronen et al., 2005b]. A general agreement between these two instruments has been found but presently too few coincident measurements are available for a definitive comparison.

\section{Data Selection and Statistical Analysis}

[20] This study is based on the GOMOS level 2 data processing version 6.0a. A new version, 6.0f, is under validation. The differences between the ozone distributions in the two versions are small. For this study we have used only GOMOS nighttime measurements. The nighttime limit was set to $108^{\circ}$ for the mean solar zenith angle at the tangent point locations in the stratosphere. Figure 3 shows the distribution of the tangent point local hour for equatorial measurements, There are about 43,000 such measurements from 134 different stars. The apparent visual star magnitudes range from -1.44 (Sirius) to 3.03 and the effective blackbody star temperatures from $2800 \mathrm{~K}$ to $39000 \mathrm{~K}$. The latitudinal and monthly distribution of these measurements is shown in Figure 4. The decrease in the number of cases in May-June, when the GOMOS malfunction took place, is clearly visible. The average monthly number of occultations varies between 200 and 500 in each latitude band of $10^{\circ}$.

[21] As mentioned above, the quality of the retrieval depends strongly on the star used. The quality was inves- 


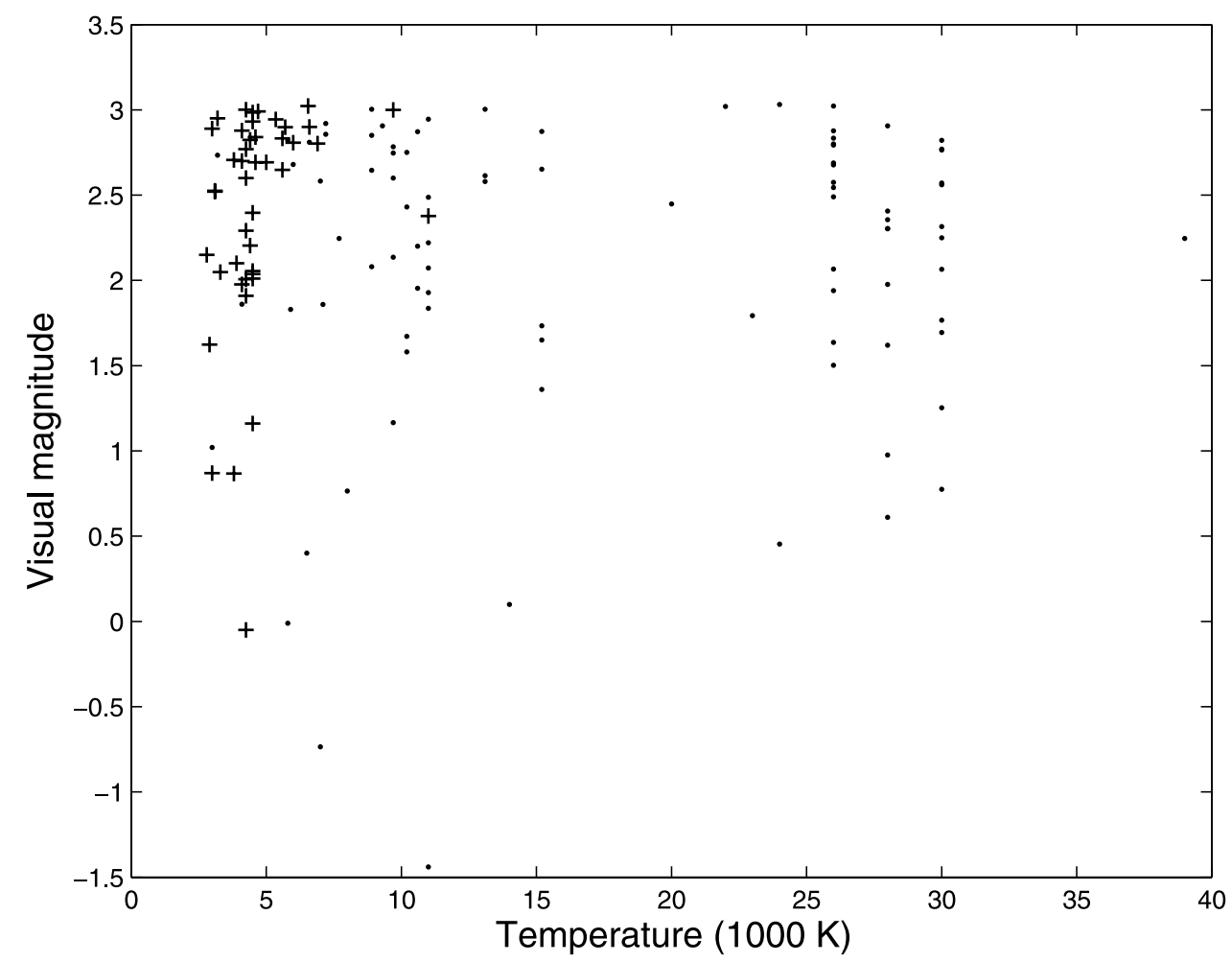

Figure 5. Distribution of GOMOS stars as a function of the visual magnitude and the effective temperature. Crosses are used to mark stars having suspicious upper altitude profiles.

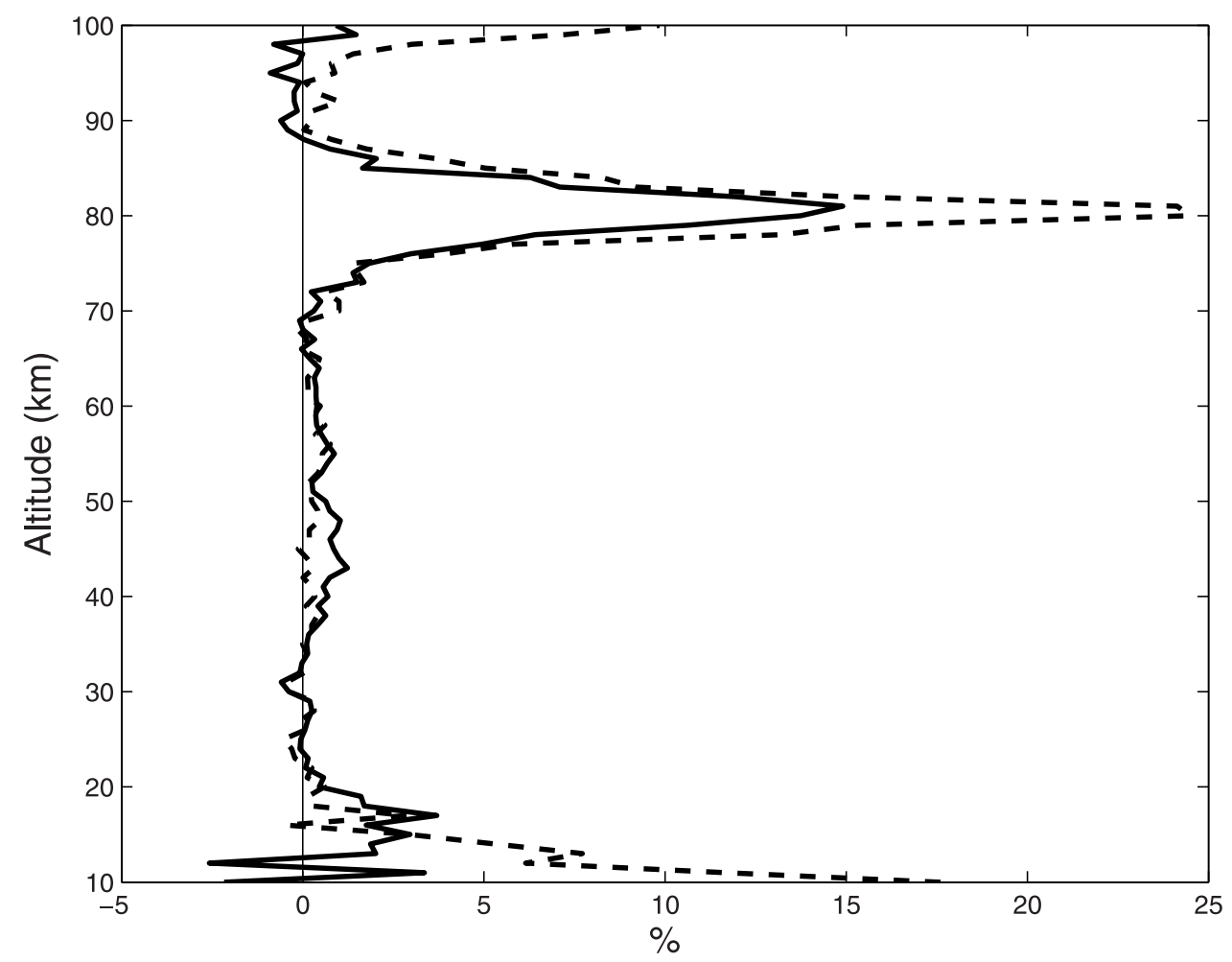

Figure 6. Differences (\%) between the mean and weighted mean estimates and the median estimate as a function of altitude. Data are from April 2003 and represent the median over latitudes. The relative difference between the mean estimator and the median is shown by the solid curve, while the dashed curve shows difference between the weighted mean and the median. 

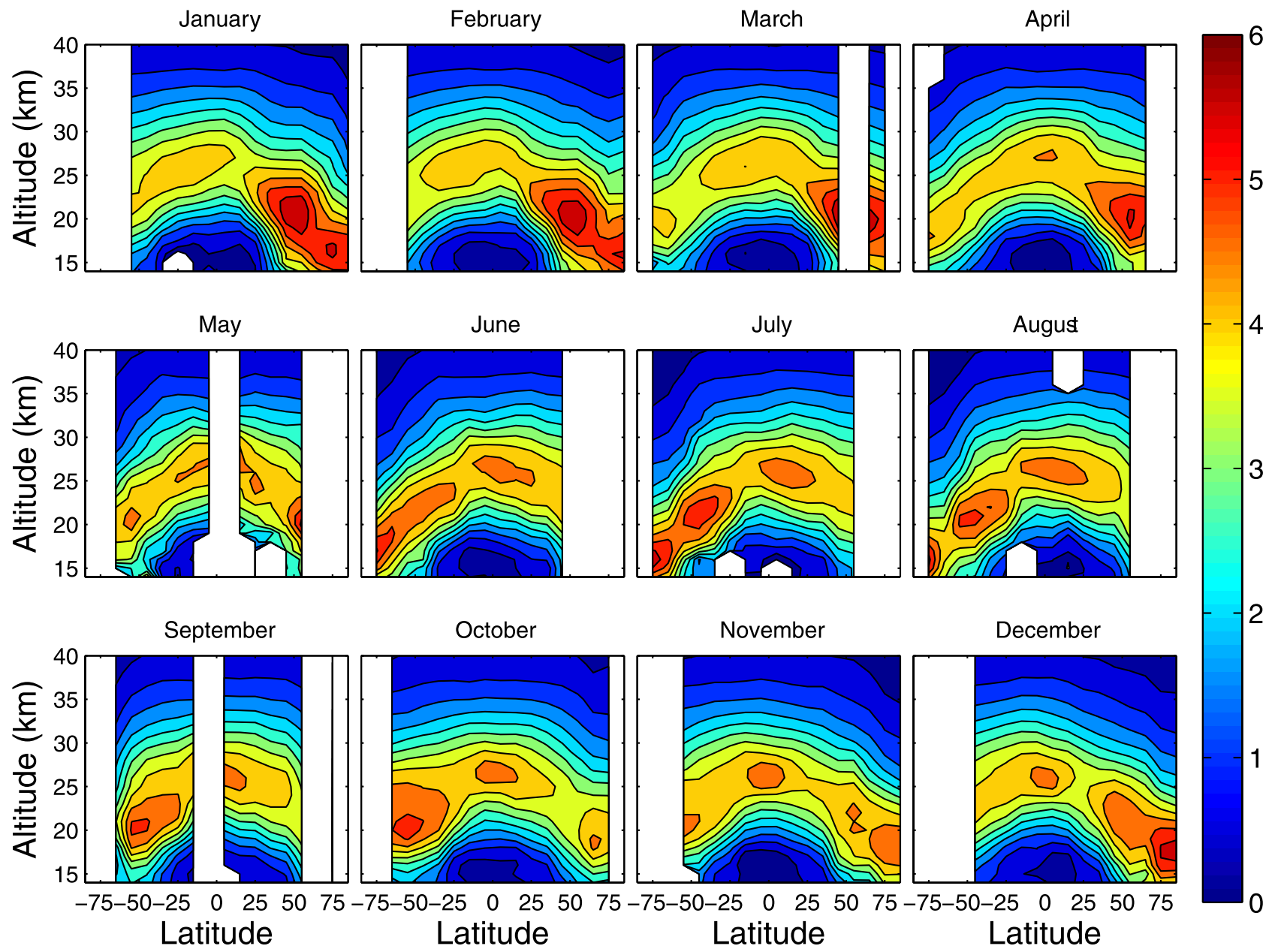

Latitude

Figure 7. Ozone number density in units of $10^{12} \mathrm{~cm}^{-3}$ from GOMOS. White areas denote missing data. Instrumental problems in May-June 2003, removal of bad stars and the restriction to dark limb measurements are the sources of missing data areas. The contours are separated by 0.5 units. The latitude range here and in other similar figures is from $90^{\circ} \mathrm{S}$ to $90^{\circ} \mathrm{N}$. Note that even in the case where data cover all latitudes, the surface plot extends only from $85^{\circ} \mathrm{S}$ to $85^{\circ} \mathrm{N}$.

tigated by checking the retrieved ozone profile statistics for each star individually. The profiles below $55 \mathrm{~km}$ were compared visually with the well-known Fortuin-Kelder ozone profile climatology [Fortuin and Kelder, 1998]. The profiles were also compared with profiles retrieved from a priori reliable stars (bright and hot) at about the same geophysical location and time. We found 44 stars that were judged as not being able to provide valid ozone profiles for the whole altitude range. These are mainly cool and weak stars (most in the region $\mathrm{T}<7000 \mathrm{~K}$ and magnitude $>1.9$ ) that cannot provide enough intensity in the UV part of the spectrum (see Figures 1 and 2 for examples). For these stars we imposed upper limits of validity (mostly in $35-45 \mathrm{~km}$ region). The upper sections of these profiles were not used in the further analysis. The number of affected occultations is large, about 12,000. Therefore the development of a more objective screening procedure will be needed in future. In Figure 5 we show the temperature and magnitude distribution of all GOMOS stars used in this study including the stars with suspicious upper altitude profiles.
[22] From individual occultations we build statistics for the ozone distribution by gridding the data. In this work we use the zonal approximation, ignoring the longitudinal variation. In the altitude direction the upper limit was set to $100 \mathrm{~km}$ and the lower limit to $5 \mathrm{~km}$ (the lowest altitudes reached by dark limb occultations vary between 5 and $20 \mathrm{~km}$ ). In the vertical direction individual, unevenly spaced GOMOS measurements were linearly interpolated to the vertical grid of $1 \mathrm{~km}$ resolution. We use a latitude grid of $10^{\circ}$ and the time averaging of 1 month.

[23] The statistical quantities calculated in the threedimensional grid (altitude, latitude, time) are mean, standard deviation, weighted mean, weighted standard deviation, median and quartiles. The weights are calculated from the error estimates included in GOMOS products. Weighted values provide a natural approach for constructing GOMOS statistical quantities because the accuracy of GOMOS results varies from one occultation to another. Generally, all the three estimates, mean, weighted mean, and median, agree reasonably well with each other (see Figure 6) everywhere else except around the ozone minimum at 

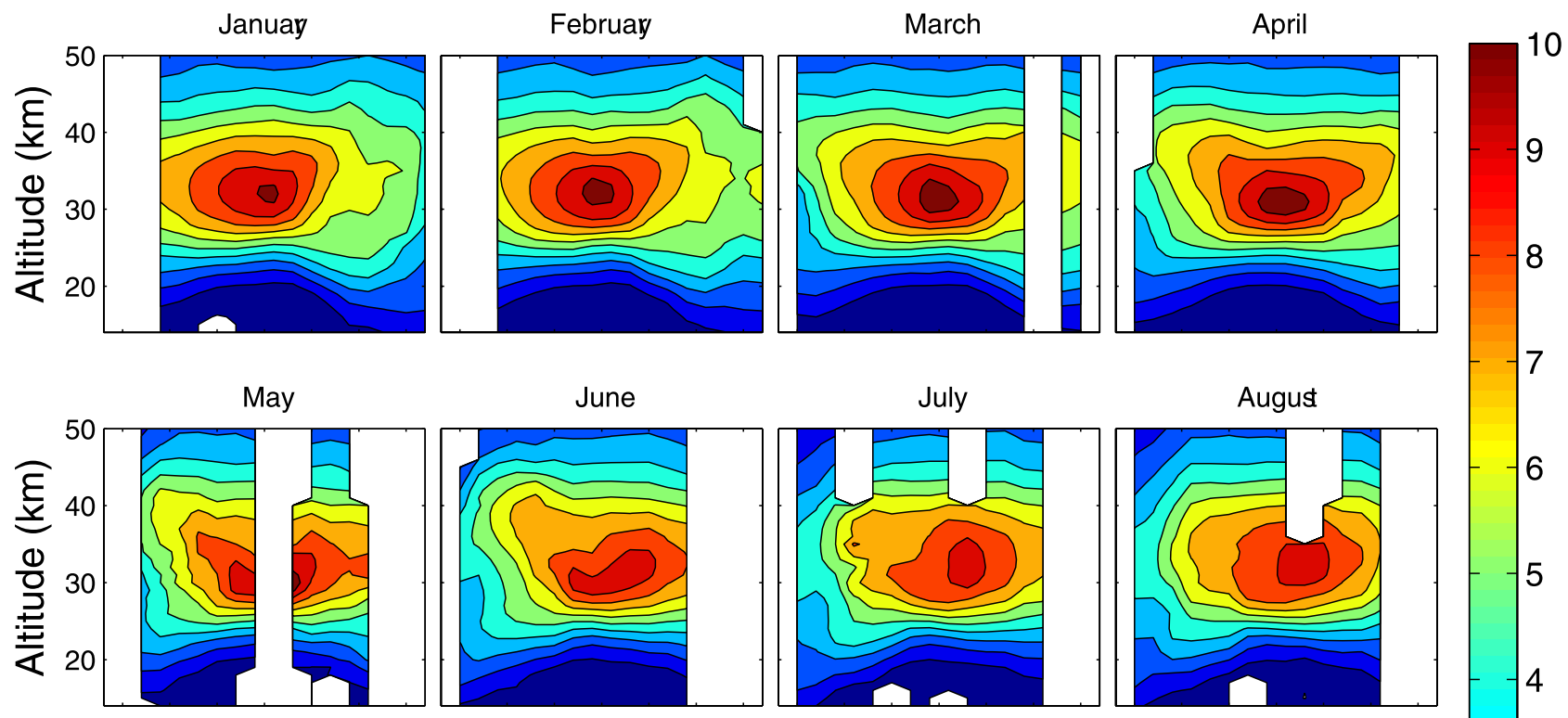

$-7$
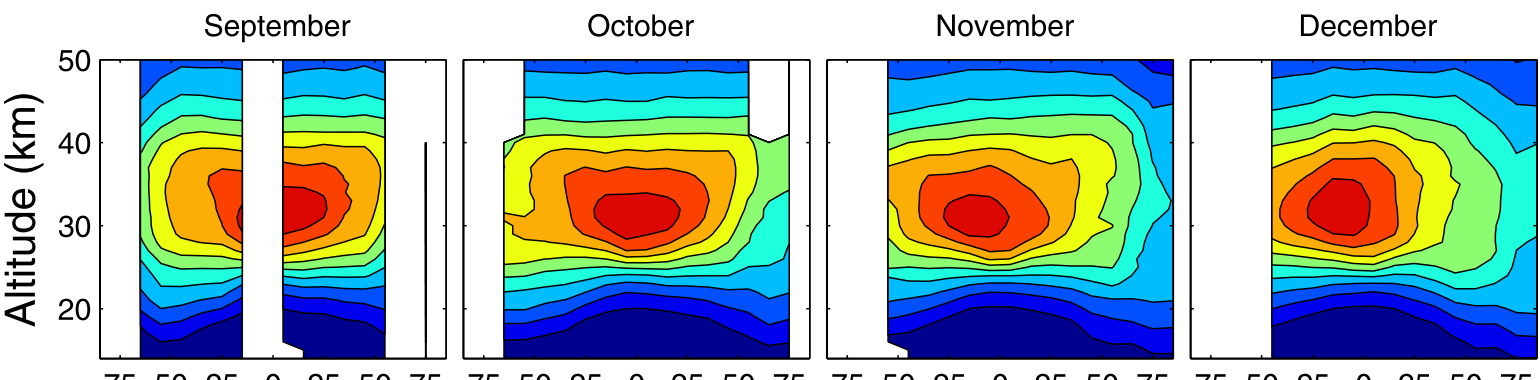

$-75-50-25 \quad 0 \quad 25$ Latitude Latitude

Latitude

Figure 8. Ozone mixing ratio in ppm from GOMOS. The contours are separated by $1 \mathrm{ppm}$. Note the upper limit of the vertical axis is $50 \mathrm{~km}$. Otherwise as in Figure 7.

$80 \mathrm{~km}$ and below $20 \mathrm{~km}$. The deviations are produced by outliers, non-Gaussian data distributions and in some cases unreliable error estimates. The outliers and a non-Gaussian distribution can emerge in a natural way because of our gridding process. In 1 month and inside $10^{\circ}$ latitude range the ozone distribution may be inhomogeneous. Taken together with the nonuniform sampling pattern of GOMOS, deviations from the normal distribution are expected. In the case where ozone density is very small (typically near $80 \mathrm{~km}$ ) the relative error is approximately equal to $\sqrt{(I)} /\left(\left|I-I_{0}\right|\right)$ where $I$ is the transmitted star intensity and $I_{0}$ the original intensity of the star. The errors grow strongly if the ozone density decreases because then $I \rightarrow I_{0}$. The current error product is unable to cope with this special case. In order to have a robust estimate we have used median and variability calculated from the interquartile range $\left(\left(q_{3}-q_{1}\right) / 2\right.$ where $q_{3}$ and $q_{1}$ are $75 \%$ and $25 \%$ percentiles, respectively) to characterize statistical distributions.

[24] The number density is a natural unit for GOMOS retrieved densities, although mixing ratios are often used in atmospheric chemistry. We evaluate ozone mixing ratios by dividing the GOMOS ozone number density by the atmospheric neutral density included in the GOMOS product.
Below $1 \mathrm{hPa}$ this is calculated from the ECMWF data and above from the MSISE-90 model [Hedin, 1991]. Because the uncertainty inherent in the model (climatology) we rely in the mesosphere and thermosphere more on number densities.

\section{Ozone in the Stratosphere}

[25] In Figure 7 we show the latitudinal distributions of the median number density profiles in the stratosphere for each month in 2003. Figure 8 shows the corresponding mixing ratio distributions. Temporal development of the number density at several latitudes is shown in Figure 9. Note that a complete seasonal coverage can be reached only for latitudes between $65^{\circ} \mathrm{S}$ to $65^{\circ} \mathrm{N}$, whereas in the polar regions the seasonal coverage is always restricted to local fall, winter and spring seasons (see Figure 4).

[26] We look first at the number density distribution. The monthly panes in Figure 7 show the well-known behavior of the ozone maximum layer in the stratosphere. The maximum layer extends for all latitudes and its altitude depends strongly on the latitude. We have analyzed the strength and altitude of the maximum. The mean altitude is at the equator $26.5 \mathrm{~km}$ and $18 \mathrm{~km}$ at $75^{\circ}$ north and south. The range of the 
$65 S$

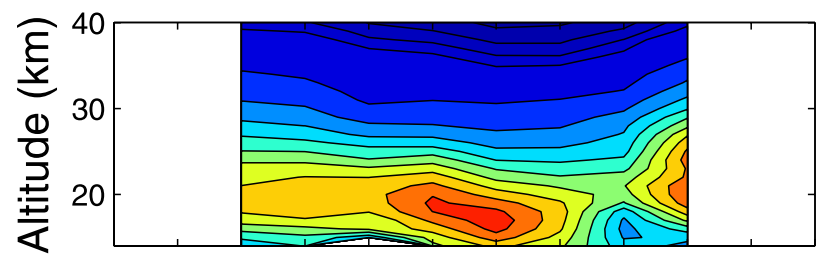

45S

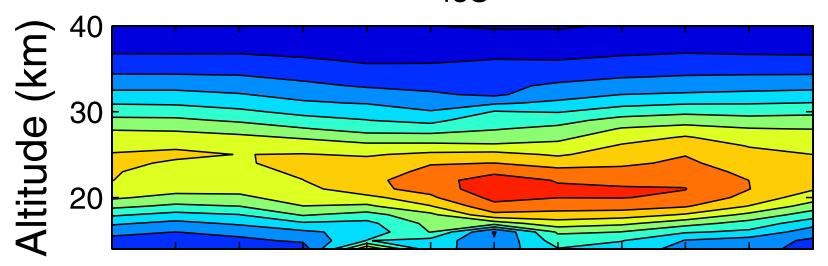

$25 S$

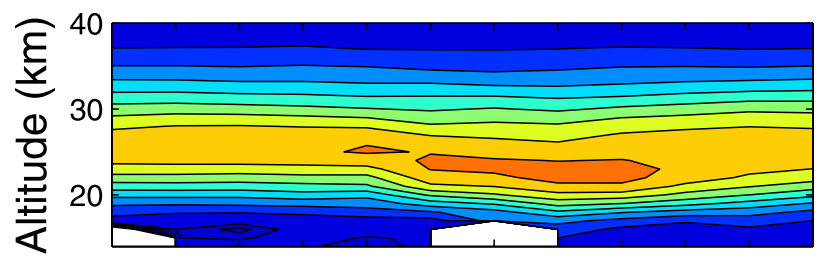

$5 S$

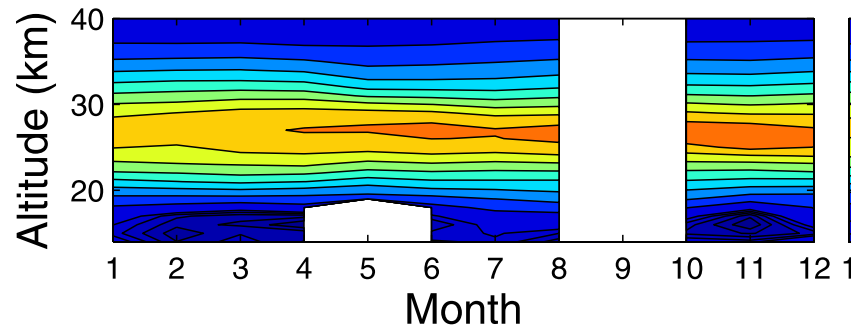

$65 \mathrm{~N}$
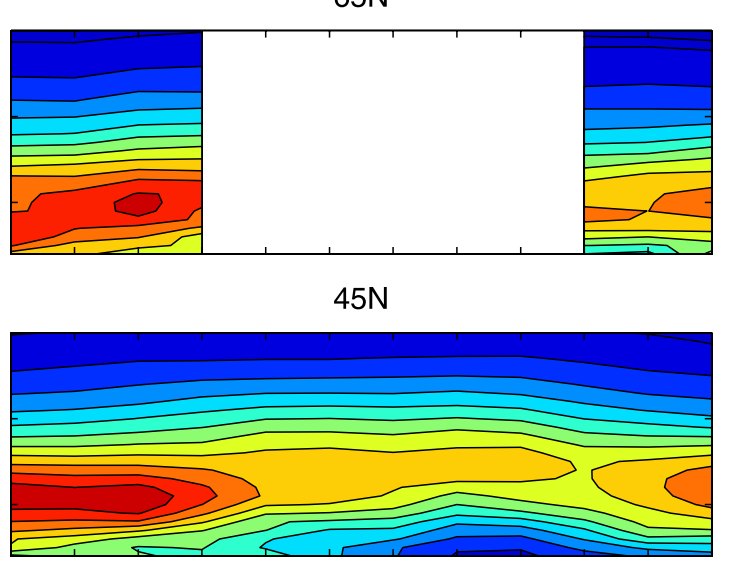

$25 \mathrm{~N}$

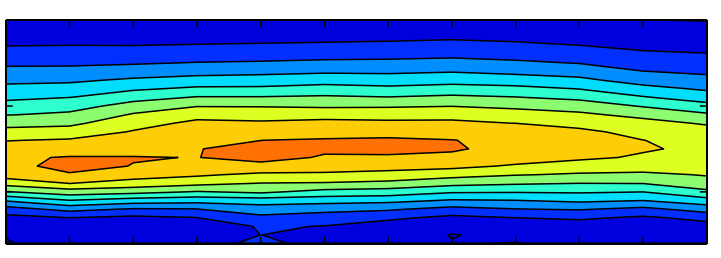

$5 \mathrm{~N}$

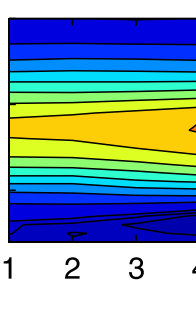

Figure 9. Time evolution of the ozone number density in units of $10^{12} \mathrm{~cm}^{-3}$ at several latitudes.

seasonal variation is $2 \mathrm{~km}$ at the equator and $5 \mathrm{~km}$ in the polar regions. The latitude distribution of the mean altitude of the maximum (in $\mathrm{km}$ ) follows quite closely the following formula:

$$
z_{\max }=26.5 e^{-(\theta / 120)^{2}} \mathrm{~km}
$$

where $\theta$ is latitude in degrees.

[27] The maximum concentration densities show clear winter-spring maxima in both hemispheres. The maximum density at a given latitude resembles but not exactly follow the quasi-harmonic oscillations found for the total ozone by Dobson [1968]. In the northern hemisphere the largest concentrations are $6 \cdot 10^{12} \mathrm{~cm}^{-3}$ in $50-60^{\circ} \mathrm{N}$ during January and February (the value in March lacking). In the southern hemisphere the largest concentrations are $5.8 \cdot 10^{12} \mathrm{~cm}^{-3}$ in $70-80^{\circ} \mathrm{S}$ during July. The development of the southern maximum is perturbed by the emergence of the yearly ozone hole in Antarctica. The mean densities are $4.5 \cdot 10^{12} \mathrm{~cm}^{-3}$ at the equator and $5.2 \cdot 10^{12} \mathrm{~cm}^{-3}$ at $75^{\circ}$ north and south.

[28] The region of the maximum ozone mixing ratio is concentrated around the equator and the maximum is relatively stable in altitude. The range in altitude for the maximum mixing ratio is from $29.5 \mathrm{~km}$ to $39 \mathrm{~km}$. The mean of the maximum altitude at the equator is $31 \mathrm{~km}, 34 \mathrm{~km}$ at $75^{\circ} \mathrm{S}$ and $35.5 \mathrm{~km}$ at $75^{\circ} \mathrm{N}$. The range of the seasonal variation is $3.5 \mathrm{~km}$ at the equator and $5 \mathrm{~km}$ in the polar regions. The maximum mixing ratios vary from 4 to 10.5 . The mean densities are $9.5 \mathrm{ppm}$ at the equator and $5.2 \mathrm{ppm}$ at $75^{\circ}$ north and south. The range at the equator is from $8.2 \mathrm{ppm}$ to $10.7 \mathrm{ppm}$ and from $4.3 \mathrm{ppm}$ to $5.2 \mathrm{ppm}$ (south) and 6.3 (north).

[29] In Figure 10 we show the relative variability of the number density profiles in \% for each month in 2003. Figure 10 covers both the stratosphere and the MLT region. The variability is generally $4-6 \%$ but much larger variation can be found in the troposphere below the ozone layer and around the ozone minimum region at $80 \mathrm{~km}$. In the polar stratosphere there is also increased variability probably associated with the planetary waves disturbing the vortex and with the polar winter downflow from the mesosphere.

\section{Comparison to Fortuin-Kelder Climatology}

[30] The density results presented above are in general qualitative agreement with the known behavior of the ozone distribution [see, e.g., Dessler, 2000; Brasseur and 

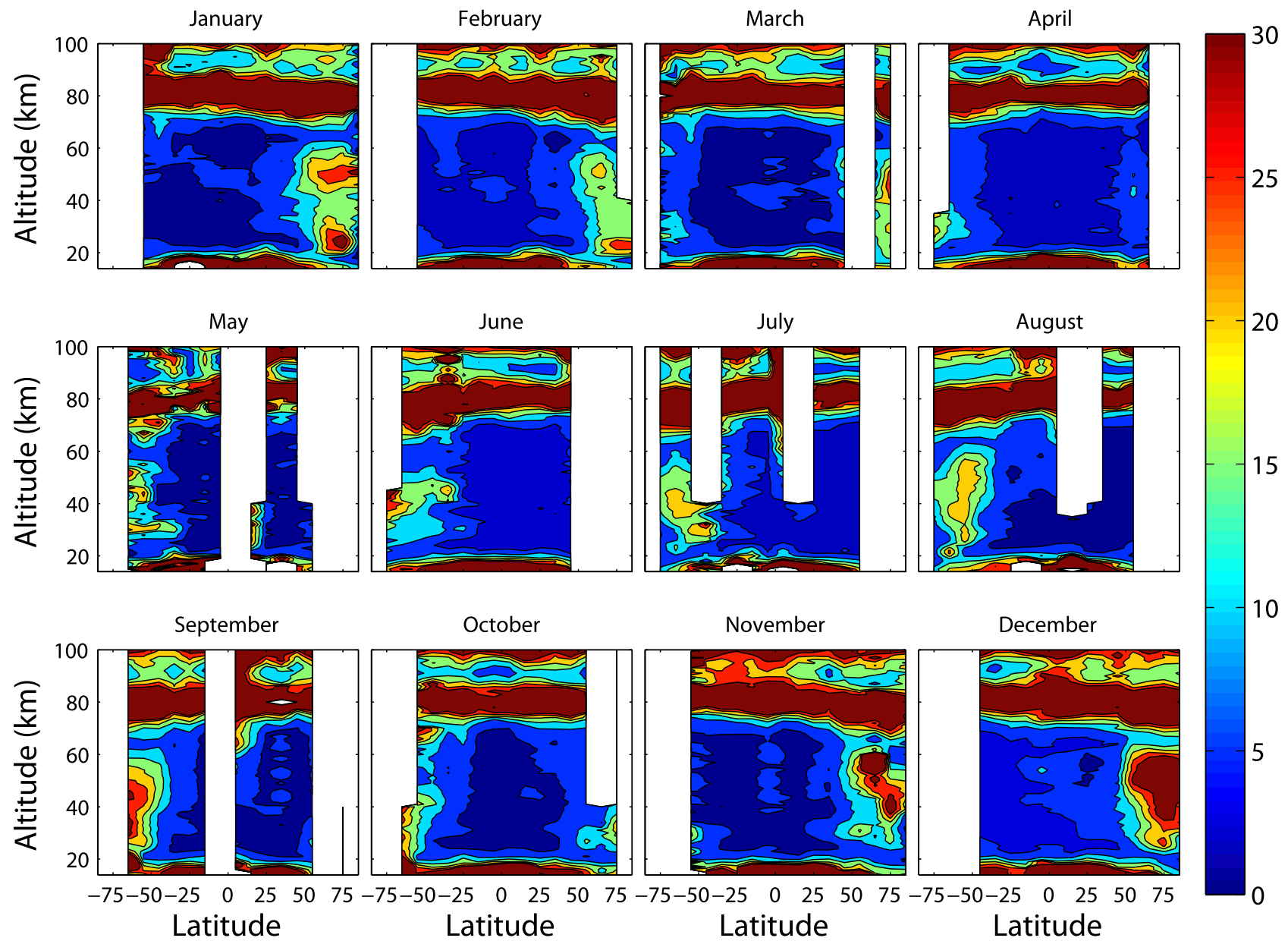

Figure 10. Relative variabilities (\%) for the ozone number density in the stratosphere and MLT. Contours are separated by $5 \%$.

Solomon, 2005]. In order to see how good the quantitative agreement is, we will compare GOMOS results with the well-known Fortuin-Kelder ozone climatology [Fortuin and Kelder, 1998, (hereinafter referred to as "F-K"). Data for F-K have been collected from sonde and satellite measurements during the period of 1980-1991.The long collection period means that $\mathrm{F}-\mathrm{K}$ includes averaging over the solar cycle, the quasi-biennial oscillations (QBO), and the anthropogenic trend. The atmospheric consequences of the Pinatubo eruption in 1991 are excluded from the data set. All data are from daytime measurements. The vertical range is from $1000 \mathrm{hPa}$ to $0.3 \mathrm{hPa}$ (about $55 \mathrm{~km}$ ).

[31] Figure 11 shows the difference between the GOMOS ozone mixing ratio median and the F-K climatology for all months in 2003. The median of the relative differences is shown in Figure 12. Because the F-K climatology is pressure-based, we use the mean value of the ECMWF pressure in the grid cells to retrieve the appropriate F-K value. According to Figure 11 GOMOS shows $5-15 \%$ larger values than F-K at all latitudes at altitudes higher than $45 \mathrm{~km}$. This is a consequence of the diurnal variation of ozone above $45 \mathrm{~km}$. The F-K climatology is based on daytime measurements and ozone values are known to increase above $45 \mathrm{~km}$ during the night. The positive region extends in the tropical region down to $30 \mathrm{~km}$ but at higher latitudes GOMOS shows smaller values than F-K already below $40 \mathrm{~km}$. In the region $20-40 \mathrm{~km}$ the solar cycle, QBO, and the anthropogenic trend all affect ozone values and from the present 1 -year comparison it is difficult to deduce anything specific about the relative contributions of these processes. The maximum impact of the solar cycle on the total ozone is known to be $2-4 \%$ [Harris et al., 1999]. In 2003 the solar cycle was between the maximum and minimum phase and therefore the impact on our results is probably small. QBO was in 2003 in a declining phase at equator. The effect of QBO on the total ozone has been found to be $2-4 \%$ and the vertical profile of the change has a two-cell structure (for details, see Harris et al. [1999]). Our deviation map shows a similar pattern but the confirmation can only be reached from a multiyear study. The SPARC study of the trends of the vertical ozone profiles [Harris et al., 1999] estimates the mean trend of the ozone profile at northern midlatitudes to be $-7.5 \%$ per decade at $40 \mathrm{~km}$. In our case this would lead to at most $-13 \%$ deviation if we take F-K to represent the state of the ozone layer in 1985. From Figure 12 we get $-5 \%$ at $65^{\circ} \mathrm{N}$ and $-1.7 \%$ at $55^{\circ} \mathrm{N}$. These values exclude summer months and they are affected by particle effects discussed next. 

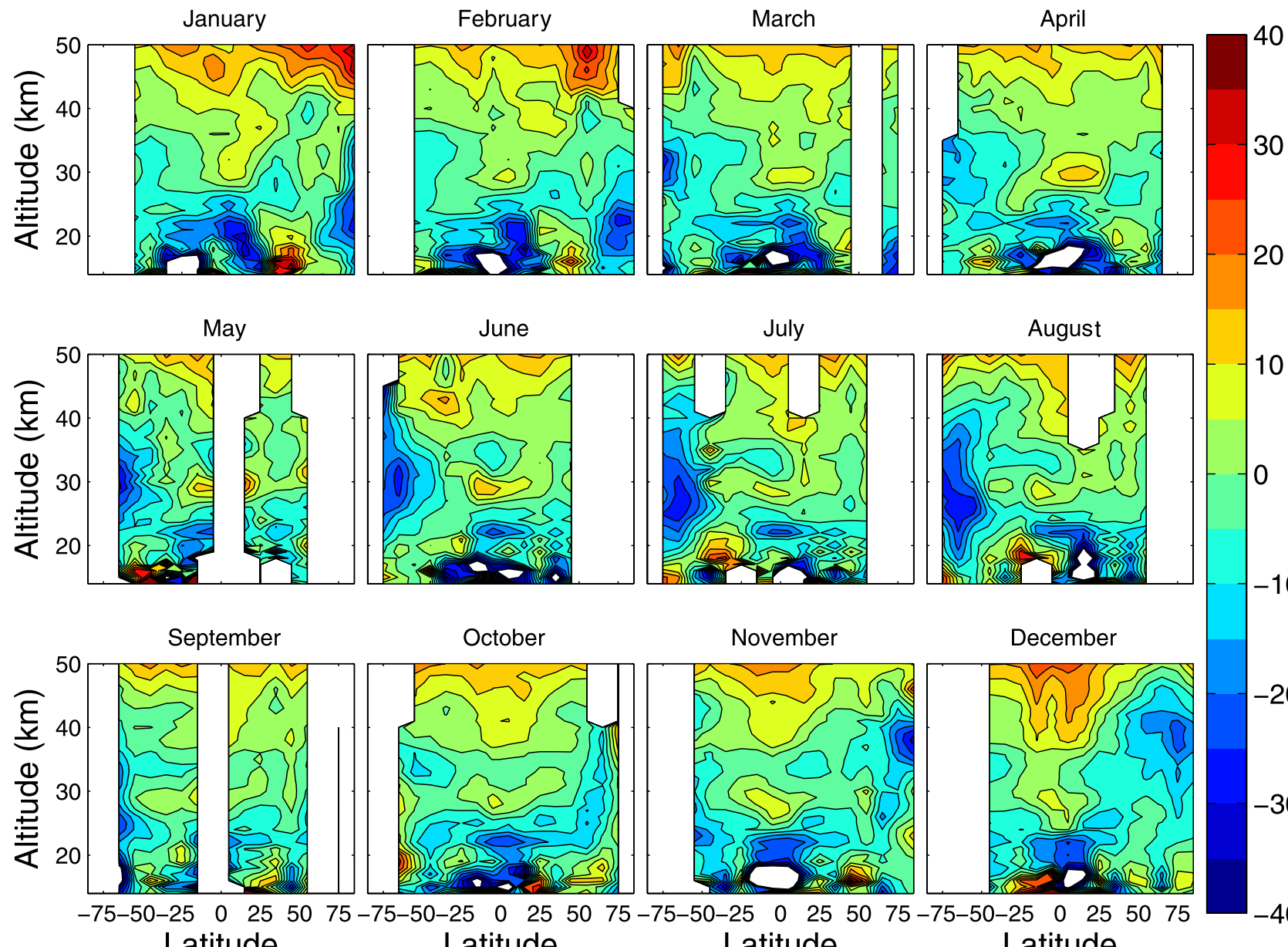

Latitude Latitude

November

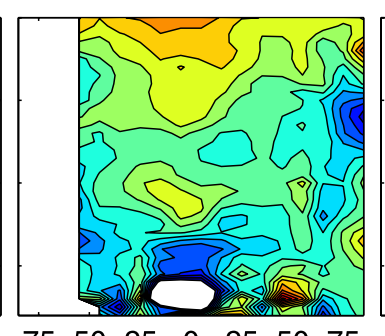

December

Figure 11. Relative difference (in \%) between GOMOS ozone mixing ratio and the F-K climatology for each month in 2003 . The contours are separated by $5 \%$.

[32] In the polar regions GOMOS shows signs of large ozone decrease compared to F-K. The loss in the northern polar region around $20 \mathrm{~km}$ in January and February (up to $-25 \%$ ) is an indication of stronger Arctic ozone loss [Singleton et al., 2005] but the losses (up to -25\%) in November-December around $40 \mathrm{~km}$ have been shown to originate from the strong solar proton storms in OctoberNovember 2003 [see, e.g., Seppälä et al., 2004; Verronen et al., 2005a]. The actual perpetrator is the large increase of $\mathrm{NO}_{2}$ during the storm. The deviations from the F-K values in the southern polar region are larger than in north (up to $-30 \%$ ) and they are taking place in winter months May-August before the real peak of the ozone hole. The maximum deviation is at $30 \mathrm{~km}$. This deviation is related to unexpected large amounts of $\mathrm{NO}_{2}$ during the winter (for monthly $\mathrm{NO}_{2}$ distributions from GOMOS [see Hauchecorne et al., 2005]). However, there seems to be no strong solar storm associated with this increase but the large $\mathrm{NO}_{2}$ amounts have been shown to originate from the electron precipitation at auroral altitudes [Funke et al., 2005]. In the comparisons with F-K we need to remember that we do not how much $\mathrm{NO}_{2}$ increases have affected the results in F-K.

[33] Around the equator in the lower stratosphere-upper troposphere GOMOS ozone mixing ratio values are much lower than F-K values. The reason for this deviation is not clear. We can first notice that the F-K climatology near the equator is based on only a few measurements and therefore the reliability of the F-K climatology is less in this region. The corresponding $\mathrm{NO}_{2}$ values are low [Hauchecorne et al., 2005] and cannot explain the deviation. Regarding the reliability of GOMOS measurements, the occurrence of convective clouds and subvisual cirrus clouds near the equator may complicate the interpretation of measurements. GOMOS measurements show a clear increase of aerosols in this region [Vanhellemont et al., 2005]. Interestingly enough, the occurrence of convective clouds and cirrus clouds can also be linked with low ozone values.

[34] In addition to profiles we can compare the vertical total ozone columns from GOMOS and F-K. GOMOS ozone profile measurements can be used to derive vertical columns with variable altitude limits. In Figure 13 we compare the 15-50 km columns from GOMOS and the F-K climatology. We can see that the total ozone retrieved by GOMOS is generally 5\% lower except in the polar regions, where the difference is greater. As already stated, this difference may be partly from the general negative trend of ozone after the F-K data were collected, but the natural variations complicate the picture. Starting in May the southernmost measurements show a strong decrease com- 


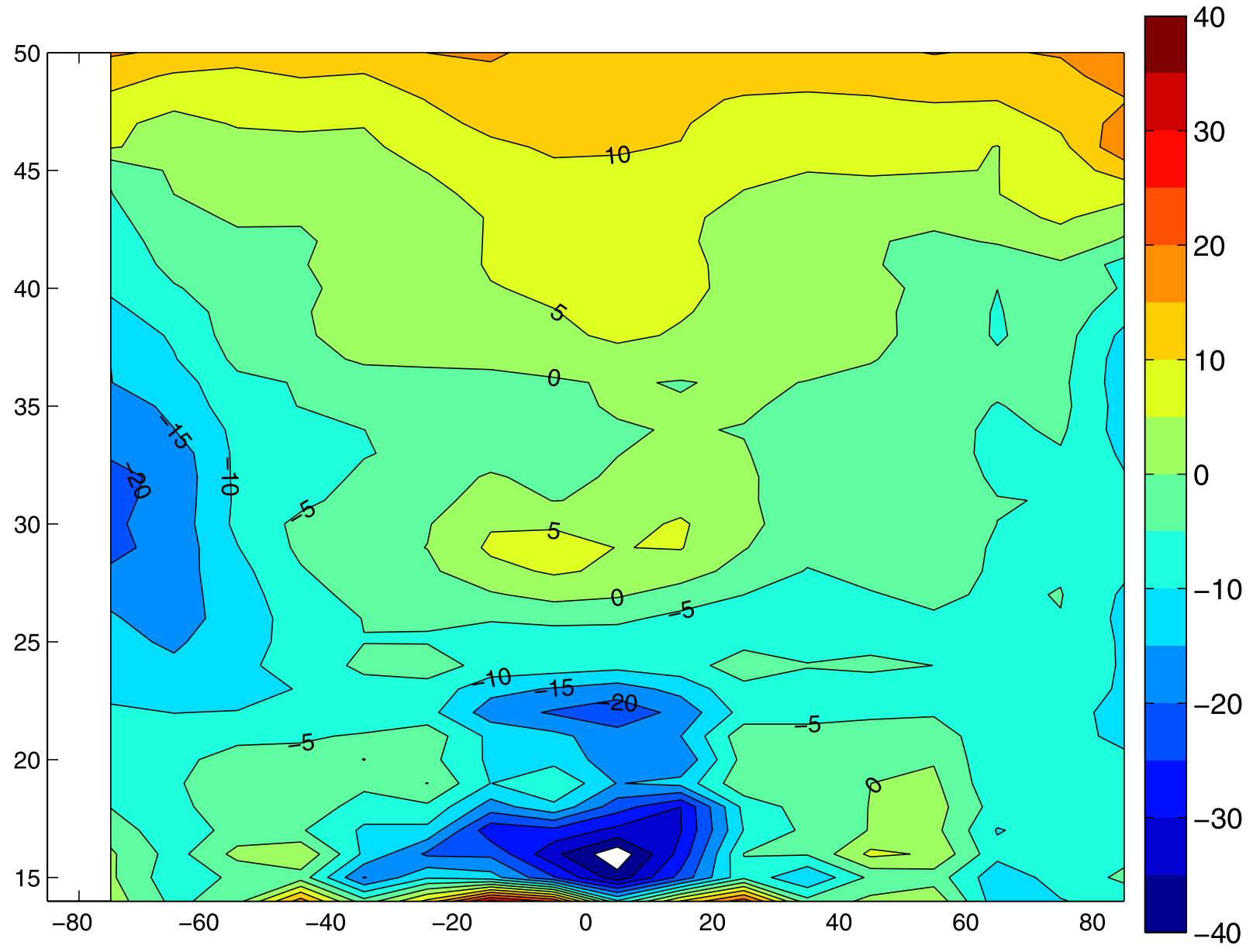

Figure 12. Median of the relative difference (in \%) between GOMOS ozone mixing ratio and the F-K climatology in 2003 . The contours are separated by $5 \%$. The horizontal axis is latitude in degrees, and the vertical axis is altitude in $\mathrm{km}$.

pared with $\mathrm{F}-\mathrm{K}$ because of the $\mathrm{NO}_{2}$ winter increase and eventually the deepening of the Antarctic ozone hole.

\section{Ozone in the Mesosphere and Thermosphere}

[35] While a fairly good understanding of ozone in the stratosphere exists, the ozone distribution in the mesosphere and lower thermosphere is still inadequately known [see Marsh et al., 2002; Kaufmann et al., 2003; Hartogh et al., 2004; Smith, 2004; Smith and Marsh, 2005]. The diurnal variation is very large and most measurements so far have taken place during daytime. Nighttime measurements have been provided by CIRRIS-1A, CRISTA, and MAS on Space Shuttle missions, MLS on UARS and the current MIPAS on Envisat and SABER on TIMED. GOMOS measurements in the mesosphere and thermosphere are very simple absorption measurements and can therefore provide unique data and new insights to the nighttime distribution of ozone in this region. The solar zenith angle limit $108^{\circ}$ together with the $10 \mathrm{pm}$ equator crossing time of Envisat mean that measurements near the equator cover a few local hours local around 10 p.m.

[36] We show the monthly number density distributions in Figure 14. Figure 15 shows the time development of the number density is shown for several latitudes. Figure 14 shows that the number density is characterized by a strong maximum region around $90 \mathrm{~km}$. It is interesting to note that this maximum was first observed from a satellite using the stellar occultation method [Hays and Roble, 1973]. The altitude of the maximum is $90 \mathrm{~km}$ at equator and $87 \mathrm{~km}$ at polar regions and it has a few $\mathrm{km}$ seasonal scatter. The distribution of the maximum density along the latitudes behaves as a function of time as a seesaw. The maximum concentrations occur in the polar areas during the local wintertime. During fall and spring the maximum areas extend toward the equator and in April and October the distribution is relatively even at all latitudes. Around the equator there is a bulge in the latitude-altitude plane. The seasonal variation at all nonpolar latitudes shows a semiannual cycle with maxima in April and October. The maximum number density follows approximately the formula:

$$
\rho=4.2 \cdot 10^{8}\left(1+\frac{1}{2} \cos \frac{2 \pi(m-4)}{12}\right) \mathrm{cm}^{-3}
$$

where $m$ is the month. In polar latitudes we cannot really follow the development of the maximum through the summer months. 


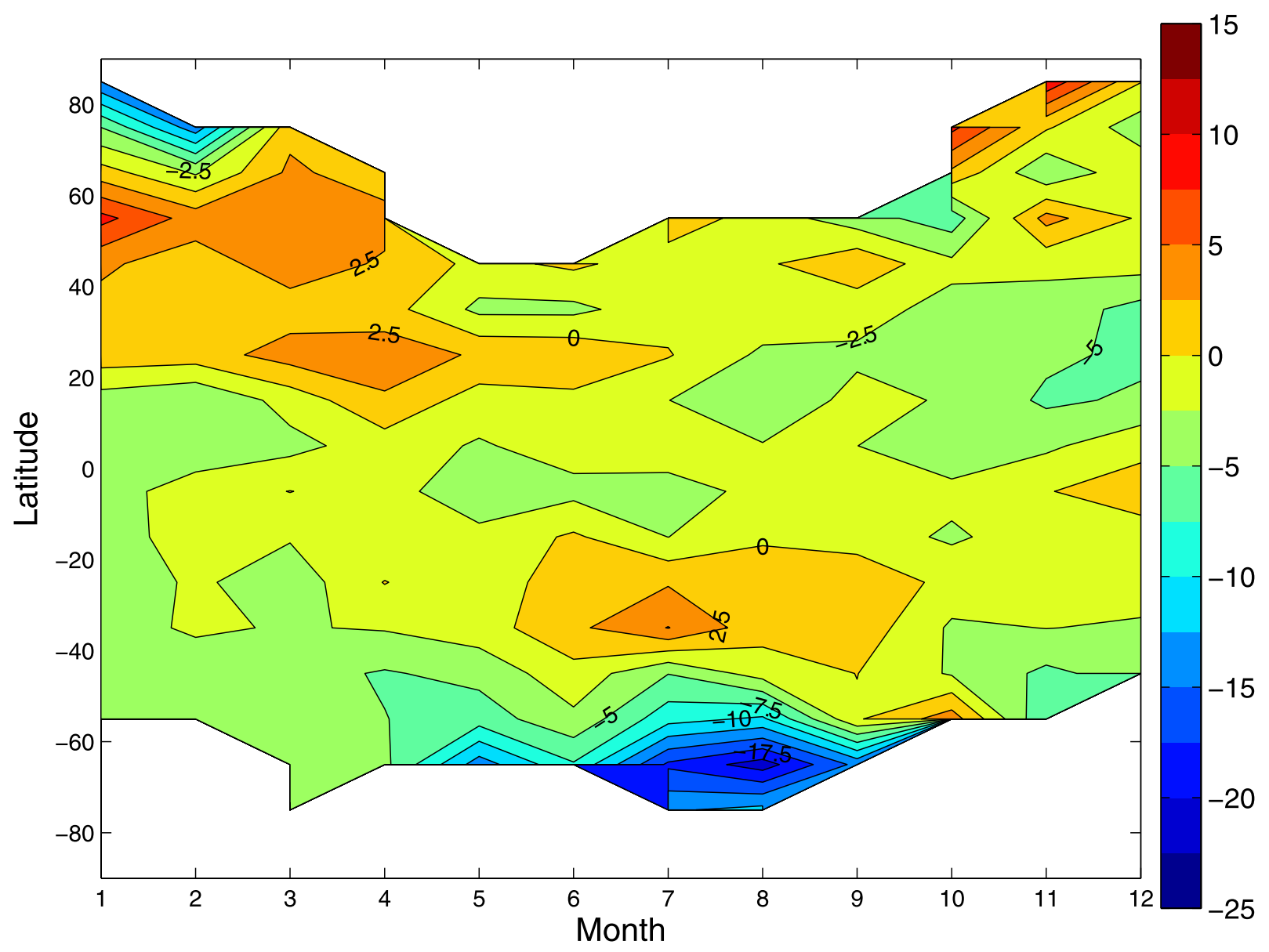

Figure 13. Relative difference in total ozone between the GOMOS observations and the F-K climatology for an altitude range of $15-50 \mathrm{~km}$. The contours are separated by $2.5 \%$.

[37] If we calculate the mixing ratio by using MSISE-90 the same overall development can be detected. The maximum layer is located around $98 \mathrm{~km}$ and varies by a few $\mathrm{km}$ as a function of latitude. The mixing ratio at the maximum is 9.8 and it follows the same semiannual cycle as the number density.

[38] Below the maximum layer there is a very deep minimum layer around $80 \mathrm{~km}$, which can be seen in both the number density and the mixing ratio. Figure 16 shows the mixing ratio calculated by using MSISE-90. Deepest values are $4 \cdot 10^{7} \mathrm{~cm}^{-3}$ for the number density and $0.13 \mathrm{ppm}$ for the mixing ratio and they are found in January at the equator. Notice that the retrieval uncertainties of GOMOS measurements are largest at the minimum. In addition to the clear minimum, Figure 16 also shows a tertiary ozone peak around $72 \mathrm{~km}$ in the polar areas during wintertime [see Marsh et al., 2001; Hartogh et al., 2004]. The third ozone maximum has been shown to be vulnerable to solar proton events [Seppälä et al., 2006].

[39] There is no earlier comprehensive MLT nighttime ozone climatology from other satellite instruments. The validation of results above need to be based on the case by case comparisons with a few earlier nighttime MLT measurements [e.g., Bevilacqua et al., 1996; Zhou et al., 1998; Kaufmann et al., 2003], presently flying MIPAS,
MLS and SABER instruments (see introduction for references), and models [e.g., Smith and Marsh, 2005]. This work will be performed in the future.

\section{Summary}

[40] The GOMOS measurements since March 2002 have shown that the instrument is able to fulfill the ozone monitoring objective that was the impetus for the GOMOS proposal in 1988. The stellar occultation measurements provide a spectacular view of the nighttime ozone distribution in the stratosphere, mesosphere, and lower thermosphere.

[41] In this work we have studied in detail the ozone distribution in 2003. The malfunction of the instrument pointing system in May-June 2003 decreased the number of occultations but more than 100,000 occultations were still available. In this study we used 43,000 nighttime measurements providing retrieved ozone values from $100 \mathrm{~km}$ down to $15 \mathrm{~km}$. Some cool and dim stars were found to provide unreliable results above $40 \mathrm{~km}$ and from these stars only results below this altitude were used in this study. Ozone distributions were given as the number density and mixing ratio. We provided the distribution in the regular $1-\mathrm{km}$ vertical grid, $10^{\circ}$ latitude grid and using 1-month temporal resolution. 

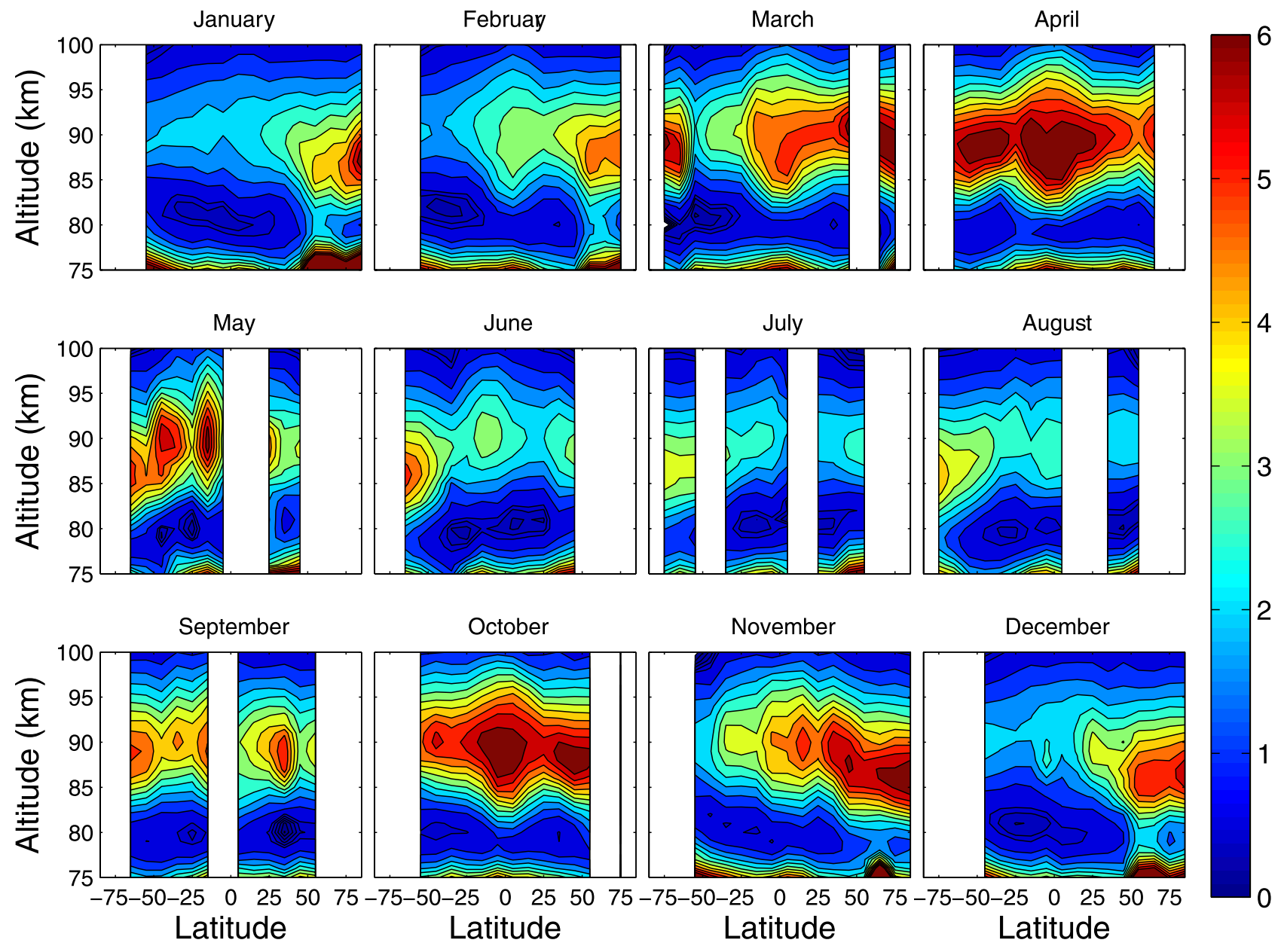

Figure 14. Ozone number density in units of $10^{8} \mathrm{~cm}^{-3}$ in MLT from GOMOS. The contours are separated by 0.5 units. 
$65 S$

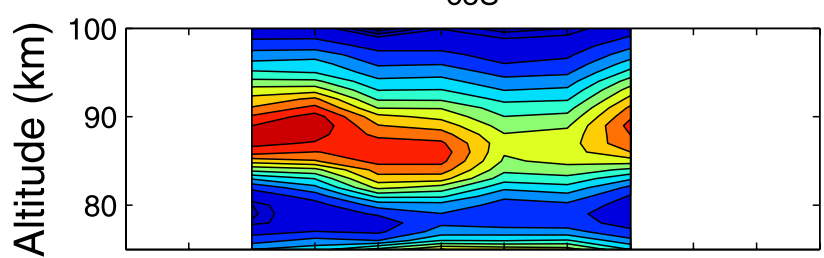

45S

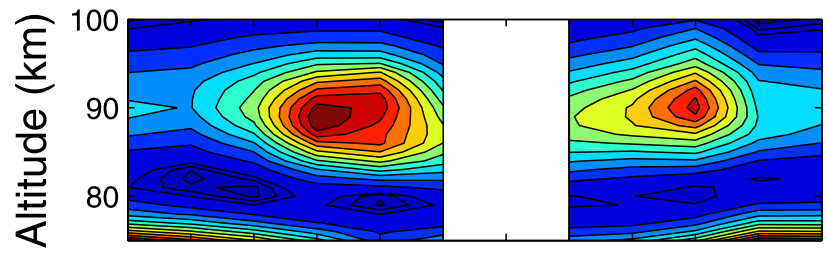

$25 S$

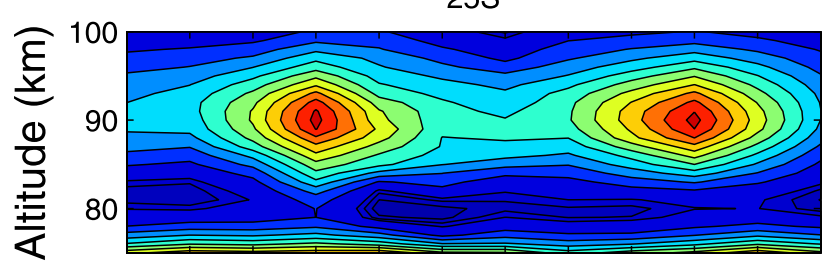

$5 S$

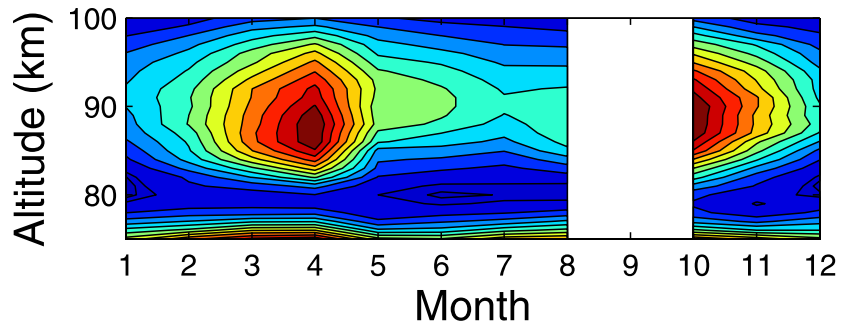

$65 \mathrm{~N}$
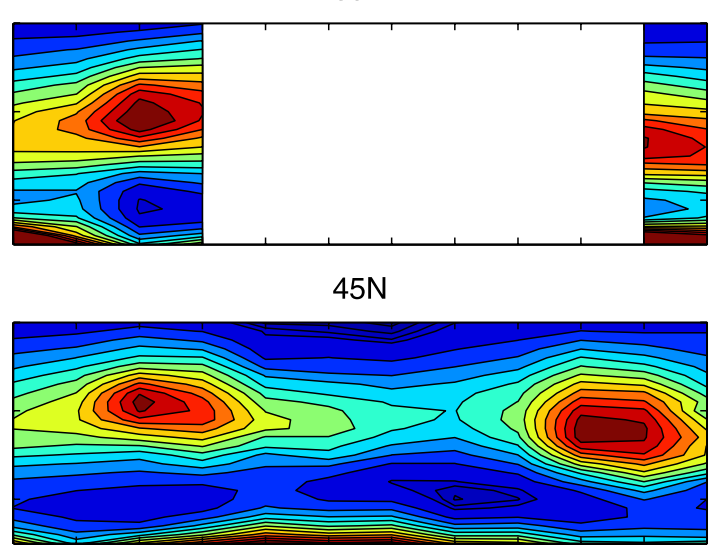

$25 \mathrm{~N}$

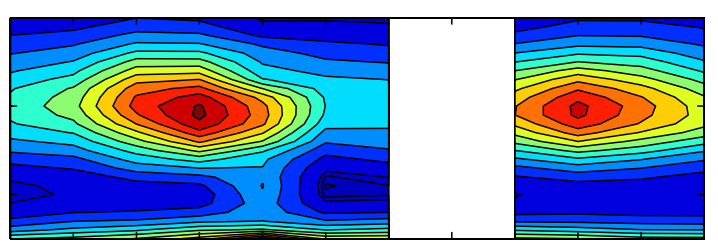

$5 \mathrm{~N}$

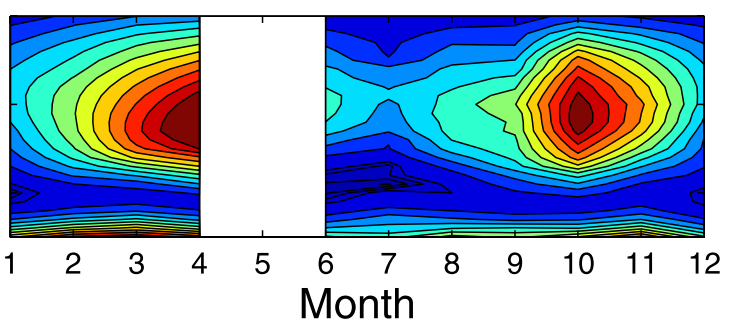

Figure 15. Time evolution of the ozone number density in MLT at several latitudes, scaled by $10^{8} \mathrm{~cm}^{-3}$. 

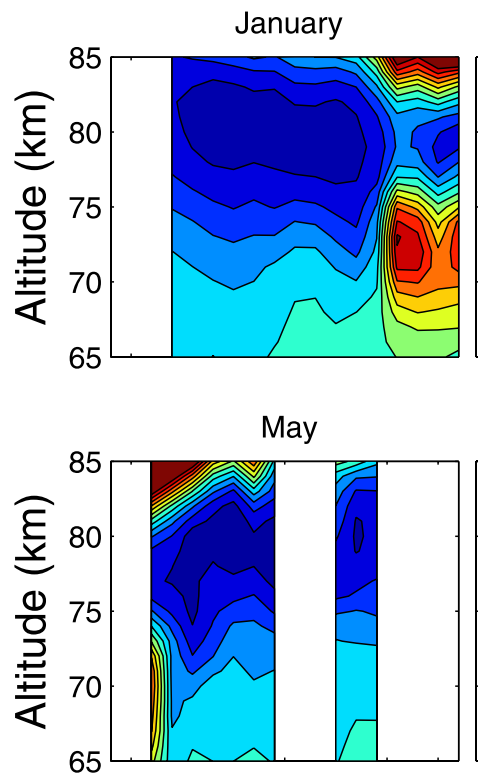

September

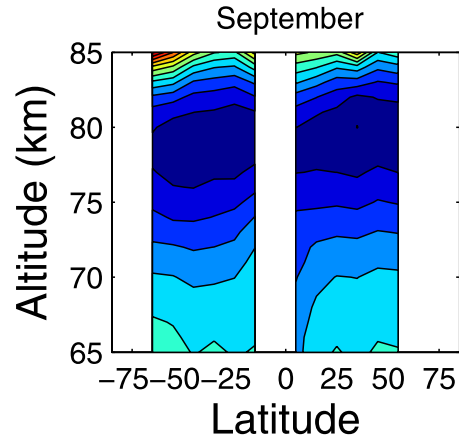

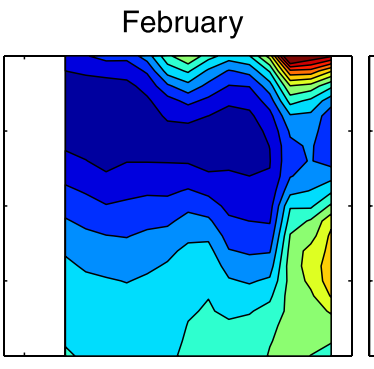

June

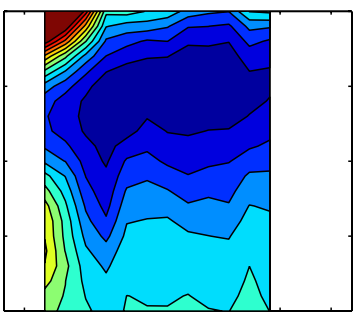

October

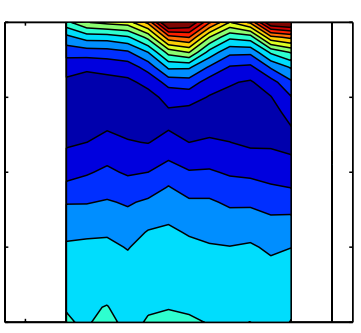

Latitude
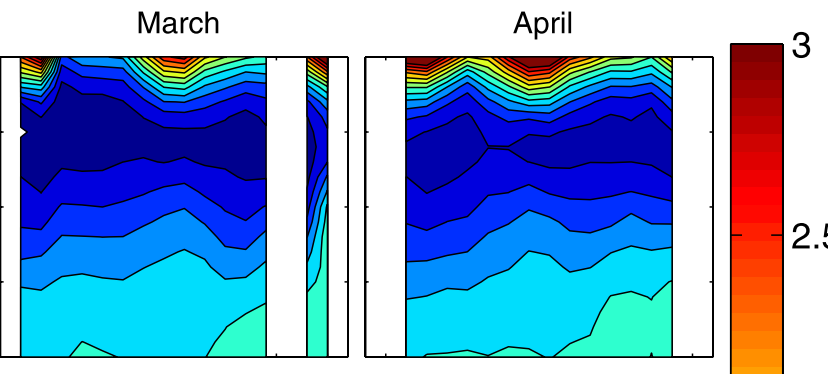

2.5

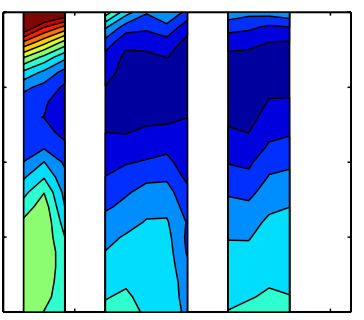

August

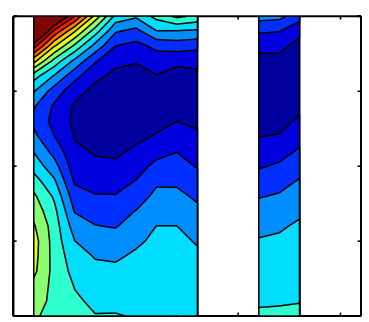

2

1.5

Figure 16. Ozone mixing ratio (ppm) below the second ozone maximum. The contours are separated by $0.25 \mathrm{ppm}$. The third ozone peak around $72 \mathrm{~km}$ in polar winter areas is easily identified.

[42] The total ozone distribution in the stratosphere is very accurately mapped by nadir viewing satellite instruments. A good understanding of the vertical profile distribution has been provided by ozone sondes, ozone lidars and a few limb scanning satellite instruments. GOMOS measurements extend profile measurements to nighttime. Especially during polar night conditions GOMOS provides valuable new data for the investigation of the development of the polar ozone loss processes. We compared GOMOS stratospheric measurements with the Fortuin-Kelder ozone climatology. In the polar night conditions signs of ozone depletion through increased $\mathrm{NO}_{2}$ concentrations have been detected. GOMOS also finds less ozone in the equatorial area near $20 \mathrm{~km}$ than the Fortuin-Kelder predicts.

[43] In the mesosphere and lower thermosphere GOMOS measurements have been used to characterize the second ozone maximum location and strength and its strong semiannual variation. The deep minimum below the maximum have also been investigated. The investigations can be valuable information for the development of the MLT models. The validation and comparison of these results with other measurements and models will be carried out in future studies.
[44] Acknowledgments. We want to thank T. Wehr, J. Langen and C. Readings, who have chaired the GOMOS Science Advisory Group during the instrument development years. We want to also thank J. P. Pommereau and P. Fortuin for valuable discussions. The three reviewers of the paper helped to improve the paper considerably.

\section{References}

Barath, F. T., et al. (1993), The Upper Atmosphere Research Satellite microwave limb sounder instrument, J. Geophys. Res., 98, 10,75110,762 .

Bertaux, J. L., G. Megie, T. Widemann, E. Chassefiere, R. Pellinen, E. Kyrölä, S. Korpela, and P. Simon (1991), Monitoring of ozone trend by stellar occultations: The GOMOS instrument, Adv. Space Res., 11(3), $237-242$.

Bertaux, J. L., E. Kyrölä, and T. Wehr (2000), Stellar occultation technique for atmospheric ozone monitoring: GOMOS on Envisat, Earth Obs. Q., 67, 17-20.

Bertaux, J. L., et al. (2004), First results on GOMOS/Envisat, Adv. Space Res., 33, 1029-1035.

Bevilacqua, R. M., et al. (1996), MAS measurements of the latitudinal distribution of water vapor and ozone in the mesosphere and lower thermosphere, Geophys. Res. Lett., 23, 2317-2320.

Bovensmann, H., et al. (2004), SCIAMACHY on Envisat: In-flight optical performance and first results, in Remote Sensing of Clouds and the Atmosphere VIII, edited by K. Schaefer et al., Proc. SPIE Int. Soc. Opt. Eng., $5235,160-173$

Bracher, A., et al. (2005), Cross comparisons of $\mathrm{O}_{3}$ and $\mathrm{NO}_{2}$ measured by the atmospheric Envisat instruments GOMOS, MIPAS, and SCIAMACHY, Adv. Space Res., 36, 855-867, doi:10.1016/j.asr.2005.04.005.

Brasseur, G. P., and S. Solomon (2005), Aeronomy of the Middle Atmosphere, 3rd revised and enlarged ed., Springer, New York. 
Chu, W. P., M. P. McCormick, J. Lenoble, C. Brogniez, and P. Pruvost (1989), SAGE II inversion algorithm, J. Geophys. Res., 94, 83398351.

Dalaudier, F., V. Kan, and A. S. Gurvich (2001), Chromatic refraction with global ozone monitoring by occultation of stars. I. Description and scintillation correction, Appl. Opt., 40(6), 866-877.

Dessler, A. (2000), The Chemistry and Physics of Stratospheric Ozone, Elsevier, New York.

Dobson, G. (1968), Exploring the Atmosphere, 2nd ed., Clarendon, Oxford, U. K.

European Space Agency (2001), Envisat-GOMOS, An Instrument for Global Atmospheric Ozone Monitoring, ESA SP-1244, Noordwijk, Netherlands.

Fischer, H., and H. Oelhaf (1996), Remote sensing of vertical profiles of atmospheric trace constituents with MIPAS limb-emission spectrometers, Appl. Opt., 35(16), 2787-2796.

Fortuin, J. P. F., and H. Kelder (1998), An ozone climatology based on ozonesonde and satellite measurements, J. Geophys. Res., 103(D24), 31,709-31,734.

Funke, B., M. López-Puertas, S. Gil-Lopez, T. von Clarmann, G. P. Stiller, H. Fischer, and S. Kellmann (2005), Downward transport of upper atmospheric NOx into the polar stratosphere and lower mesosphere during the Antarctic 2003 and Arctic 2002/2003 winters, J. Geophys. Res., 110, D24308, doi:10.1029/2005JD006463.

Glaccum, W., et al. (1996), The Polar Ozone and Aerosol Measurement instrument, J. Geophys. Res., 101(10), 14,479-14,488.

Grant, W. B. (Ed.) (1989), Ozone Measuring Instruments for the Stratosphere, Opt. Soc. of Am., Washington, D. C.

Gurvich, A. S., F. Dalaudier, and V. F. Sofieva (2005), Study of stratospheric air density irregularities based on two-wavelength observation of stellar scintillation by Global Ozone Monitoring by Occultation of Stars (GOMOS) on Envisat, J. Geophys. Res., 110, D11110, doi:10.1029/ 2004JD005536.

Harris, N., R. Hudson, and C. Phillips (1999), Assessment of Trends in the Vertical Distribution of Ozone, World Meteorol. Organ., Geneva, Switzerland.

Hartogh, P., C. Jarchow, G. R. Sonnemann, and M. Grygalashvyly (2004), On the spatiotemporal behavior of ozone within the upper mesosphere/ mesopause region under nearly polar night conditions, J. Geophys. Res., 109, D18303, doi:10.1029/2004JD004576.

Hauchecorne, A., et al. (2005), First simultaneous global measurements of nighttime stratospheric $\mathrm{NO}_{2}$ and $\mathrm{NO}_{3}$ observed by Global Ozone Monitoring by Occultation of Stars (GOMOS)/Envisat in 2003, J. Geophys. Res., 110, D18301, doi:10.1029/2004JD005711.

Hays, P. B., and R. G. Roble (1968), Stellar spectra and atmospheric composition, J. Atmos. Sci., 25, 1141-1153.

Hays, P. B., and R. G. Roble (1973), Observation of mesospheric ozone at low latitudes, Planet. Space Sci., 21, 273-279, doi:10.1016/0032-0633 (73)90011-1.

Hedin, A. E. (1991), Extension of the MSIS thermospheric model into the middle and lower atmosphere, J. Geophys. Res., 96, 1159-1172.

Kaufmann, M., O. A. Gusev, K. U. Grossmann, F. J. Martín-Torres, D. R. Marsh, and A. A. Kutepov (2003), Satellite observations of daytime and nighttime ozone in the mesosphere and lower thermosphere, J. Geophys. Res., 108(D9), 4272, doi:10.1029/2002JD002800

Kyrölä, E., E. Sihvola, Y. Kotivuori, M. Tikka, T. Tuomi, and H. Haario (1993), Inverse theory for occultation measurements: 1. Spectral inversion, J. Geophys. Res., 98, 7367-7381.

Kyrölä, E., et al. (2004), GOMOS on Envisat: An overview, Adv. Space Res., 33, 1020-1028.

Logan, J. A. (1994), Trends in the vertical distribution of ozone: An analysis of ozonesonde data, J. Geophys. Res., 99, 25,553-25,585.

Lucke, R. L., et al. (1999), The Polar Ozone and Aerosol Measurement (POAM) III instrument and early validation results, J. Geophys. Res., 104(D15), 18,785-18,800.

Marsh, D., A. Smith, G. Brasseur, M. Kaufmann, and K. Grossmann (2001), The existence of a tertiary ozone maximum in the high latitude middle mesosphere, Geophys. Res. Lett., 28(24), 4531-4534.

Marsh, D. R., W. R. Skinner, A. R. Marshall, P. B. Hays, D. A. Ortland, and J. Yee (2002), High Resolution Doppler Imager observations of ozone in the mesosphere and lower thermosphere, J. Geophys. Res., 107(D19), 4390, doi:10.1029/2001JD001505.

Meijer, Y. J., et al. (2004), Pole-to-pole validation of Envisat/GOMOS ozone profiles using data from ground-based and balloon-sonde measurements, J. Geophys. Res., 109, D23305, doi:10.1029/2004JD004834.
Murtagh, D., et al. (2002), An overview of the Odin atmospheric mission, Can. J. Phys., 80(4), 309-319.

Roble, P. B., and R. Hays (1972), A technique for recovering the vertical number density profile of atmospheric gases from planetary occultation data, Planet. Space Sci., 94, 1727-1744.

Russell, I. J. M., M. G. Mlynczak, L. L. Gordley, J. Tansock, and R. Esplin (1999), An overview of the SABER experiment and preliminary calibration result, Proc. Soc. Photo Opt. Instrum. Eng., 3756, 277-288.

Russell, J. M., et al. (1993), The Halogen Occultation Experiment, J. Geophys. Res., 98(17), 10,777-10,797.

Seppälä, A., P. T. Verronen, E. Kyrölä, S. Hassinen, L. Backman, A. Hauchecorne, J. L. Bertaux, and D. Fussen (2004), Solar proton events of October-November 2003: Ozone depletion in the Northern Hemisphere polar winter as seen by GOMOS/Envisat, Geophys. Res. Lett., 31, L19107, doi:10.1029/2004GL021042.

Seppälä, A., P. T. Verronen, V. F. Sofieva, J. Tamminen, E. Kyrölä, C. J. Rodger, and M. A. Clilverd (2006), Destruction of the tertiary ozone maximum during a solar proton event, Geophys. Res. Lett., 33, L07804, doi:10.1029/2005GL025571.

Sihvola, E. (1994), Coupling of spectral and vertical inversion in the analysis of stellar occultation data, Geophys. Publ., 38, Finn. Meteorol. Inst., Helsinki.

Singleton, C. S., et al. (2005), 2002-2003 Arctic ozone loss deduced from POAM III satellite observations and the SLIMCAT chemical transport model, Atmos. Chem. Phys., 5, 597-609.

Smith, A. K. (2004), Physics and chemistry of the mesopause region, J. Atmos. Sol. Terr. Phys., 66, 839-857.

Smith, A. K., and D. R. Marsh (2005), Processes that account for the ozone maximum at the mesopause, J. Geophys. Res., 110, D23305, doi:10.1029/ 2005JD006298.

Sofieva, V. F., J. Tamminen, H. Haario, E. Kyrölä, and M. Lehtinen (2004), A priori smoothness on ozone profile smoothness in the inversion from limb measurements, Ann. Geophys., 22(10), 3411-3420.

Solomon, S. (1999), Stratospheric ozone depletion: A review of concepts and history, Rev. Geophys., 37(3), 275-316.

Staehelin, J., N. R. P. Harris, and C. Appenzeller (2001), Ozone trends: A review, Rev. Geophys., 39, 231-290.

Vanhellemont, F., et al. (2005), A first comparison of GOMOS aerosol extinction retrievals with other measurements, Adv. Space Res., 36, 894-898, doi:10.1016/j.asr.2005.04.094.

Verronen, P. T., A. Seppälä, M. A. Clilverd, C. J. Rodger, E. Kyrölä, C.-F. Enell, T. Ulich, and E. Turunen (2005a), Diurnal variation of ozone depletion during the October-November 2003 solar proton events, J. Geophys. Res., 110, A09S32, doi:10.1029/2004JA010932.

Verronen, P. T., et al. (2005b), A comparison of night-time GOMOS and MIPAS ozone profiles in the stratosphere and mesosphere, Adv. Space Res., 36, 958-966.

Yee, J., et al. (2002), Atmospheric remote sensing using a combined extinctive and refractive stellar occultation technique: 1. Overview and proof-of-concept observations, J. Geophys. Res., 107(D14), 4213, doi:10.1029/2001JD000794.

Zhou, D. K., M. G. Mlynczak, G. E. Bingham, J. O. Wise, and R. M. Nadile (1998), CIRRIS-1A limb spectral measurements of mesospheric 9.6- $\mu \mathrm{m}$ airglow and ozone, Geophys. Res. Lett., 25, 643-646.

G. Barrot, O. Fanton d'Andon, M. Guirlet, A. Mangin, and B. Theodore, ACRI-ST, F-06904 Sophia-Antipolis Cedex, France.

J. L. Bertaux, F. Dalaudier, and A. Hauchecorne, Service d'Aeronomie du Centre National de la Recherche Scientifique, BP 3, F-91371 Verrieresle-Buisson Cedex, France.

T. Fehr, R. Koopman, and L. Saavedra de Miguel, European Space Research Institute, European Space Agency, I-00044 Frascati, Italy.

R. Fraisse, EADS-Astrium, 31 Avenue des Cosmonautes, F-31402 Toulouse Cedex 4, France.

D. Fussen and F. Vanhellemont, Institut d'Aeronomie Spatiale de Belgique, Avenue Circulaire 3, B-1180 Brussels, Belgium.

S. Hassinen, E. Kyrölä, G. W. Leppelmeier, A. Seppälä, V. Sofieva, J. Tamminen, and P. T. Verronen, Earth Observation, Finnish Meteorological Institute, P.O. Box 503, FIN-00101 Helsinki, Finland. (erkki. kyrola@fmi.fi)

Y. J. Meijer, National Institute for Public Health and the Environment, NL-3720 BA Bilthoven, Netherlands.

P. Snoeij, European Space Research and Technology Centre, European Space Agency, NL-2200 AG Noordwijk, Netherlands. 